\title{
The Role of Gut Microbiota Biomodulators on Mucosal Immunity and Intestinal Inflammation
}

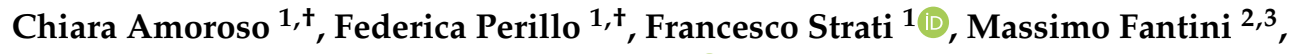 \\ Flavio Caprioli ${ }^{4,5}$ and Federica Facciotti ${ }^{1, * \mathbb{D}}$ \\ 1 Department of Experimental Oncology, IEO European Institute of Oncology IRCCS, 20139 Milan, Italy; \\ chiara.amoroso@ieo.it (C.A.); federica.perillo@ieo.it (F.P.); Francesco.strati@ieo.it (F.S.) \\ 2 Gastroenterology Unit, Duilio Casula Hospital, AOU Cagliari, 09042 Cagliari, Italy; \\ massimoc.fantini@unica.it \\ 3 Department of Medical Science and Public Health, University of Cagliari, 09124 Cagliari, Italy \\ 4 Department of Pathophysiology and Transplantation, Università degli Studi di Milano, 20135 Milan, Italy; \\ flavio.caprioli@unimi.it \\ 5 Gastroenterology and Endoscopy Unit, Fondazione IRCCS Cà Granda, Ospedale Maggiore Policlinico, \\ 20135 Milan, Italy \\ * Correspondence: federica.facciotti@ieo.it \\ + These authors equally contributed.
}

Received: 26 April 2020; Accepted: 13 May 2020; Published: 16 May 2020

check for updates

\begin{abstract}
Alterations of the gut microbiota may cause dysregulated mucosal immune responses leading to the onset of inflammatory bowel diseases (IBD) in genetically susceptible hosts. Restoring immune homeostasis through the normalization of the gut microbiota is now considered a valuable therapeutic approach to treat IBD patients. The customization of microbe-targeted therapies, including antibiotics, prebiotics, live biotherapeutics and faecal microbiota transplantation, is therefore considered to support current therapies in IBD management. In this review, we will discuss recent advancements in the understanding of host-microbe interactions in IBD and the basis to promote homeostatic immune responses through microbe-targeted therapies. By considering gut microbiota dysbiosis as a key feature for the establishment of chronic inflammatory events, in the near future it will be suitable to design new cost-effective, physiologic, and patient-oriented therapeutic strategies for the treatment of IBD that can be applied in a personalized manner.
\end{abstract}

Keywords: inflammatory bowel diseases; gut microbiome; live biotherapeutic products; FMT

\section{Background}

The pathogenesis of inflammatory bowel diseases (IBD) is still incompletely understood. However, the combination of genetic and environmental factors in the context of host-microbe interactions appears to trigger IBD-initiating events. Impairment of intestinal barrier functions, which results in the translocation of gut microbes, promotes the hyper-activation of the mucosal immune system and the production of pro-inflammatory cytokines that altogether contribute to fuelling the inflammation observed in IBD patients [1-3]. The gut microbiome is a complex microbial ecosystem that co-evolved a mutualistic relationship with the host complementing its functions through dietary fibre fermentation, pathogen defence and biosynthesis of vitamins and essential metabolites. The mutual interaction between the gut microbiota and the host is further highlighted by its role in sustaining the maturation and functioning of the host's immune system contributing to host's homeostasis [4]. Indeed, the intestine and its associated immunological components have to deal with several, in some cases dichotomous, tasks. Apart from all the functions related to digestion and absorption of nutrients, the intestine has to be tolerant towards mutualistic/commensal microorganisms and to keep control over pathobionts 
(i.e., those resident microbes with pathogenic potential), preventing microbial overgrowth and invasion of the epithelial intestinal barrier. In turn, the gut microbiota has to modulate and regulate several aspects of host's immune system towards tolerance rather than responsiveness. Any disruption of this delicate equilibrium has potentially pathological consequences on the health status of the host. Dysbiosis (i.e., altered microbial composition) of the gut microbiota can lead to chronic inflammation as observed in IBDs. IBDs appear to be caused by a dysregulated immune response to commensal microorganisms harbouring virulence traits in their genome (the so-called pathobionts) in genetically susceptible hosts. In this review, we will discuss the relationship between the microbiota and the immune system in IBD patients. We will recapitulate the mechanisms by which the gut microbiota and the immune system reciprocally influence their functions in homeostasis and during IBD as well as the basis for therapeutic restoration of homeostatic immune function by manipulating the gut microbiota through existing microbe-targeted therapies, including antibiotics, prebiotics, probiotics, and faecal microbiota transplantation.

\section{Mucosal Immune Dysfunctions and Dysbiotic Microbiota in IBD}

It is now clear that IBD is a polymicrobial disease with a combination of various gut microbial factors, abnormal immune responses and a weakened intestinal mucosal barrier leading to aberrant host immune responses against commensal bacteria [5]. Over the last years, through genome-wide association studies (GWAS) in diverse populations, genetic variants and candidate gene networks that affect host-microbe interactions such as Toll-like receptor (TLR) and nucleotide-binding oligomerization domain (NOD)-like receptor (NLR) signalling have been identified [6]. IBD loci are also markedly enriched in genes involved in primary immunodeficiencies, which are characterized by a dysfunctional immune system. These genes correlate with reduced levels of circulating T-cells (ADA, CD40, TAP1/2, NBS1, BLM, DNMT3B), or of specific subsets such as T helper (Th)-17 (STAT3), memory (SP110), or regulatory T-cells (STAT5B) [7]. Intestinal epithelial barrier integrity defects are frequently observed in IBD. Indeed, the epithelial barrier plays a critical role in maintaining intestinal homeostasis because it lies at the interface between luminal microbes and the host immune system, while also being the first site of exposure to many of the environmental factors that can act as triggers of disease activity [8]. Accordingly, several genes closely related to IEC-specific functions, such as ATG16L1, KCNN4, XBP1, may promote the susceptibility to IBD [9].

It has been observed that the TNF- $\alpha$-TNFR2 signalling pathway in intestinal epithelial cells (IECs) increases the expression of myosin light chain kinase (MLCK), and thereby disrupt the assembly of the tight junctions (TJ) [10], suggesting that proinflammatory cytokine may further enhance the "leakiness" of the epithelial layer. Moreover, inflammation may induce the so called "depletion of goblet cells" determining the loss of proper mucin secretion [11] and a deregulated IL-7 cytokine production, leading to chronic inflammation [12]. Expression of antimicrobial peptides is mostly reduced in IBD. IBD candidate risk loci, in particular those with mutations in the CARD15 gene, encoding the bacterial-sensing protein NOD2, have been associated with reduced $\alpha$-defensin production (i.e., DEFA5 and DEFA6) in both adult and pediatric ileal patients with CD [13,14].Also the CD risk allele ATG16L1 predisposes Paneth cells to lose their ability to form normal intracellular granules [15], resulting in a lower production of antimicrobial peptides [16]. Thus, defects in epithelial cell barrier function lead to chronic exposure to bacterially derived molecules leading to the destructive intestinal inflammation that characterize IBD [17].

Th17 cells abundantly exist in the LP of the small intestine [18] and they not only protect the host against infection, but their hyper-activation also cause autoimmune inflammation in the gut [19]. The gut microbiota has a very strong influence on the frequency of Th17. Segmented filamentous bacteria $(S F B)$ presence, for example, is sufficient to induce the appearance of classical mucosal CD4+ Th17 cells coproducing interleukin (IL)-17 and IL-22 [20] with distinct T cell receptor (TCR) clonotype [21]. A functional plasticity of Th17 cells towards a Th1 lineage has been demonstrated, which is dependent on the presence of IL-12 and IL-23 produced by antigen-presenting cells (APCs) 
in response to bacteria-derived signals, both in murine models and IBD patients [22]. Nizzoli and colleagues recently demonstrated that pathogenicity of IL-17-secreting cells isolated from Crohn's disease (CD) patients and from colitic animals were directly dependent on Interferon- $\gamma$ (IFN- $\gamma$ ) secretion, as demonstrated by the reduced colitogenic activity of Th17 cells isolated from IFN- $\gamma-/-$ mice [22]. Paradoxically, secukinumab, a monoclonal antibody used as treatment for dermatological and rheumatological disease which acts by blocking of the IL-17 pathway, is associated to IBD onset in approximately $1 \%$ of patients $[23,24]$. This contradictory effect may be due to the fact that IL-17 seems to act as protector against inflammation, contributing to the inhibition of the Th1 response and maintaining the integrity of the enterocyte's epithelial barrier and intestinal homeostasis [25].

Alterations in the composition of the commensal microbiota, such as bifidobacteria and lactobacilli, can influence also the frequency of mucosal Treg cells, which are known to play a pivotal role in the pathogenesis of IBD [26], as demonstrated by the fact that mice lacking Treg cells develop spontaneous colitis [27]. Similarly, children with mutations in the IL-10 receptor develop early-onset $C D$ [28]. Nevertheless, increased numbers of Foxp3+Tregs and high levels of their signature cytokines TGF- $\beta$ and IL-10 have been reported in inflamed intestinal lesions of IBD patients as well as in colitic animals [29] suggesting that inflammation can promote Treg expansion and accumulation in inflamed lesions. Gram-positive commensal bacteria play a dominant role in maintaining Treg homeostasis [30], as confirmed by the experiments where reconstitution of Germ-Free (GF) mice with Gram-positive spore-forming microorganisms, restored the Treg population [31]. It has been demonstrated that the culture supernatant of IECs from Clostridium-colonized mice markedly enhanced the differentiation of Foxp3-expressing cells, showing that Clostridia activate IECs to produce TGF- $\beta$ and other Treg-inducing molecules within the colon [30]. In particular, F. prausnitzii skewed human dendritic cells (DCs) to prime IL-10-secreting T cells and to express a unique array of potent type 1 regulatory $\mathrm{T}$ (Tr1)/Treg polarizing molecules such as IL-10, IL-27, CD39, indoleamine 23-dioxygenase 1 (IDO-1) and programmed death-ligand 1 (PDL-1). Following TLR4 stimulation, F. prausnitzii is also able to reduce the up-regulation of co-stimulatory molecules as well as the production of the pro-inflammatory cytokines IL-12 (p35 and p40) and Tumor Necrosis Factor (TNF)- $\alpha$ [32]. These data suggest that the composition of the gut microbiota may affect human colonic homeostasis by acting on the DCs- Treg cells induction axis [32].

Inducible (i)Treg cells, suppressive cells which develop from mature CD4+ conventional T cells outside of the thymus and which are involved in mucosal tolerance, are induced and maintained by gut microbes [33,34]; these cells have been thoroughly studied in the pathogenesis of IBD. The decreased percentage of iTreg may lead to autoimmune responses and tissue damage in the acute phase of IBD, although it has not been conclusively ruled out if iTreg takes part in promoting intestinal homeostasis during the recovery stage [35].

Invariant natural killer T (iNKT) cells are critical players in the mucosal immune responses [36], but their role in IBD has not been completely elucidated. iNKT cells have been reported to contribute to experimental intestinal inflammation [37], and those isolated from IBD patients have a pro-inflammatory phenotype manifesting pathogenic features upon exposure to intestinal mucosaassociated microbiota [38]. However, it has also been shown that iNKT cells contribute to intestinal homeostasis by interacting with CD1d-expressing, IL10 producing, epithelial cells [39] and that iNKT cells protect mice from experimental colitis [40-42], albeit in IBD patients a protective role for iNKT cells has not been proven yet. B. fragilis effectively regulates iNKT cell proliferation during neonatal development, thanks to the inhibitory effects of its glycosphingolipid GSL-Bf717. When B. fragilis is present in the eubiotic microbiota, total colonic iNKT cell numbers are restricted into adulthood by recognition of GSL-Bf717, and the host is protected against experimental oxazolone-induced colitis [36]. Moreover, B. fragilis colonization can reverse CD4+T-cell defects and Th1/Th2 imbalance in GF mice [43] and can protect from experimental colitis induced by Helicobacter hepaticus.

Innate lymphoid cells (ILCs), in particular ILC3s, are also thought to be important in the pathogenesis of IBD [44]. IL-17-producing ILC3 cells are increased in inflamed intestines in patients 
with Crohn Disease (CD) [44]. IL-22 +ILC3s deficiency, found in both the intestinal mucosa of animal models and patients with IBD, causes intestinal mucosal barrier damage, leading to exposure of intestinal tissue to a large number of antigens [45]. Moreover, production of IL-22 by ILC3s is required for protective immunity towards pathobionts, such as Citrobacter rodentium, since mice lacking ILC3s or IL-22 quickly succumb to the infection [46]. Macrophages and DCs are also involved in gut bacteria recognition during intestinal inflammation $[29,47]$. In IBD patients, during the inflammatory processes, monocytes move into the intestine to differentiate into macrophages and DCs and the latter express higher levels of TLR-2 and TLR-4, which may contribute to an altered immune response to commensals, and of CD40 [48]. Consequently, an increased production of proinflammatory cytokines, such as IL-1, IL-6, TNF, IL-18 and members of the IL-12 family is observed [48]. Furthermore, neutrophils show an important antimicrobial function that relies on the formation of neutrophil extracellular traps (NETs) [49]. The generation and/or clearance of aberrant NETs has been associated with several immune diseases [50] including Ulcerative Colitis (UC), where excessive NETs formation in response to TNF- $\alpha$ stimulation can amplify pathogenic signals in the gut [51]. It has been shown that Candida albicans might interact with mucosal innate immune cells through the pathways associated with Dectin-1 in macrophages [52] and TLR4 in neutrophils and by inducing the proliferation and differentiation of B-lymphocytes accompanied with increased number of Immunoglobulin (Ig)A-secreting plasma cells [53]. Eukaryotic viruses are also involved in intestinal inflammatory processes. Infection with the murine norovirus in genetically predisposed mice triggers the alteration of Paneth cells activity and the inflammatory response when treated with dextran sodium sulphate (DSS), by modulating the cytokines TNF- $\alpha$ and IFN- $\gamma$, as well as by inducing alterations in the composition of the commensal microbiota [54].

\section{Manipulation of the Gut Microbiota for Therapeutic Purposes in Intestinal Inflammation}

The conventional treatments for IBD mainly aim at suppressing the enhanced immune response by the use of steroids, thiopurines, biologic medicines (i.e., anti-TNF, or anti-IL-12/23), small molecules including anti-Janus kinases (JAK) inhibitors, and molecules blocking the homing of pathogenic immune cells in the inflamed gut (i.e., anti-integrins) [55]. The use of anti-TNF agents has dramatically changed the management of IBD in the last decades [56] but did not change the long-term course in certain subsets of paediatric CD patients [57] as well as the frequency of hospitalization in CD patients [58]. Furthermore, the availability of multiple compounds for IBD treatment advocates the identification of variables or bio-markers able to predict therapeutic outcomes to find the best candidate drug to a given treatment. A phase-IV explorative prospective interventional trial aimed at identifying immunological variables associated with response to vedolizumab (VDZ) in patients with UC and CD demonstrated that the baseline immunological profiling of circulating and mucosal Th lymphocytes, in particular CXCR3+ Th cells, are associated with both clinical and endoscopic response to VDZ [59]. In addition, the baseline serum levels of IL- 6 and IL- 8 were associated with positive clinical outcomes in UC patients treated with VDZ; thus, an early assessment of these cytokines in UC patients treated with VDZ could lead to significant savings in terms of health care resources [60]. Accordingly, a recent work demonstrated that the levels of IL-6 may allow for the prediction of clinical response at 12 months of biological therapy thus helping to design personalized treatment strategies [61]. These biological drugs may also act by restoring the composition of the gut microbiota, as we discuss below, such as adalimumab, which is able to control inflammation by normalizing both the levels of $C$ reactive protein (CRP), and the intestinal microbial community structure [62].

However, these immunosuppressive therapies are not always effective, are quite expensive and potentially induce serious side effects. Therefore, it is desirable to develop personalized strategies to identify which patients should be treated with which drugs [63] by leveraging a more physiological approach, patient centred, with limited toxicity and high cost-effectiveness. Based on the current knowledge in the pathogenesis of IBD, microbe-targeted therapies aimed at restoring gut dysbiosis and immune homeostasis in IBD patients seems to be promising therapeutic options. Indeed, several therapies 
among which antibiotic treatments, probiotics and prebiotics administration as well as FMT have been explored to target and modulate gut microbiota composition, including both microbial physiology and/or their metabolites, that cause or contribute to inflammation directly or indirectly [64] (Figure 1).

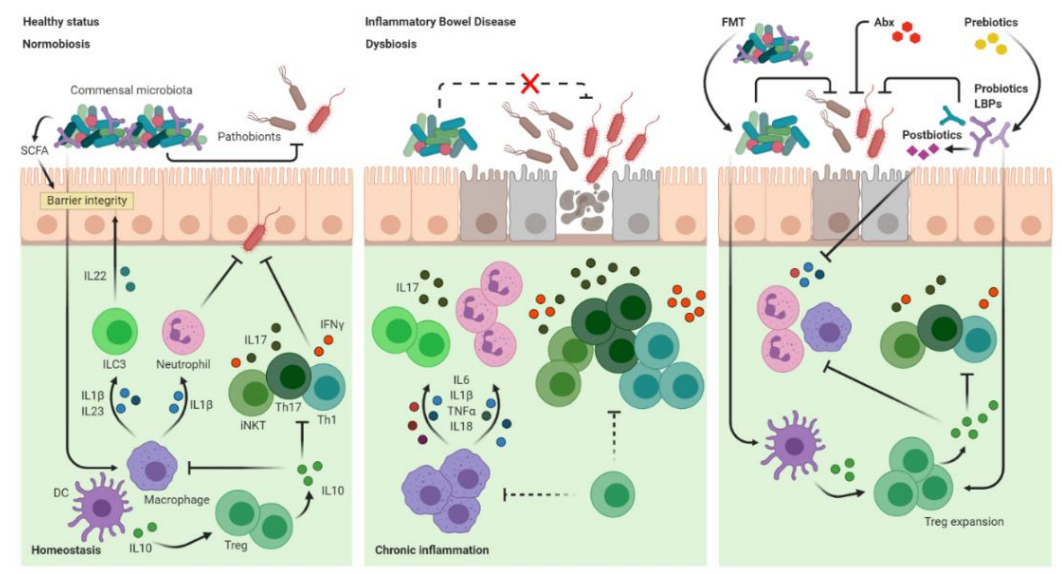

Figure 1. Homeostatic and pro-inflammatory role of the gut microbiota and microbe-targeted therapies for IBD management. During homeostasis (left panel), the recognition of specific PAMPs from the gut microbiota induces antigen presenting cells (APCs) like macrophages and dendritic cells (DC) to produce IL1 $\beta$ and IL23. Subsequently, different cell-types such as neutrophils, Th17 and ILC3 cells express cytokines (e.g., IL17 and IL22) that control the expansion of commensals and the potential invasion of microbes that could be harmful (pathobionts). The production of short-chain fatty acids (SCFAs), by the gut microbiota, in concert with IL22, enhances intestinal epithelial cell barrier function. Furthermore, commensals such as bifidobacteria, PSA $+B$. fragilis and Clostridium spp. stimulates APCs to promote anti-inflammatory IL10 Treg responses regulating iNKT, Th1 and Th17 responses. In inflammatory bowel disease (IBD) (central panel) a combination of genetic and environmental factors lead to depletion of protective bacteria and the enrichment of colitogenic pathobionts, resulting in chronic inflammation due to hyper-activation of T helper 1 (Th1) and Th17 cells as well as aberrant innate, pro-inflammatory responses. Dashed lines show impaired responses. The use of microbe-targeted therapies (right panel) to restore homeostatic immune responses contribute to the expansion of anti-inflammatory responses by Treg cells and the modulation of pro-inflammatory cytokines release.

\subsection{Antibiotics}

Since it is now acknowledged which bacterial species may have a role in IBD patients, the selective administration of different antibiotics has been used to control intestinal inflammation. Accordingly, ciprofloxacin, metronidazole or rifaximin are used to reduce the abundance of pathobionts [65] (Table 1). Treatment of colitic mice with minocycline, a semi-synthetic second-generation tetracycline, induced a reduction of pro-inflammatory cytokines [66]. Ciprofloxacin and metronidazole are commonly administered to $C D$ patients [67] and are effective for anal lesions and delay of postoperative recurrence in CD [68] by reducing TNF- $\alpha$, IL-1 $\beta$ and IL-8 [69] or by inducing long-term changes in the immune phenotype of Tregs and naive T-cells [70]. Rifaximin, a non-absorbable antibiotic, showed an excellent safety profile and coupled with a reduction of colonic inflammation and bacterial translocation in the mesenteric lymph nodes (MLNs) [71]; however, it does not yet have validated efficacy [72]. Despite some favourable clinical effects, the use of broad-spectrum antibiotics strongly affects the composition of the gut microbiota hampering the reconstitution of the gut microbiota and promoting a pro-inflammatory phenotype in the long term. Indeed, we recently demonstrated how a short-term treatment with broad-spectrum antibiotics profoundly affected the frequency and function of intestinal iNKT cells, but not of CD4+ T cells in the absence of intestinal inflammation [37]. Reconstitution of the gut microbiota after antibiotic treatment was sufficient to imprint colonic iNKT and CD4+ T cells toward a Th1-Th17 pro-inflammatory phenotype, capable to aggravate clinical conditions upon intestinal inflammation [37]. 
Table 1. Microbe-targeted therapies for IBD.

\begin{tabular}{|c|c|c|c|c|}
\hline Authors & Model/Study Case & Treatment & Outcomes & References \\
\hline \multicolumn{5}{|l|}{ Antibiotics } \\
\hline N. Garrido-Mesa et al. & $\begin{array}{l}\text { - } \quad \text { TNBS-induced colitis Wistar rats and } \\
\text { DSS-induced colitis C57BL/6J mice } \\
\text { - } \quad \text { Intestinal epithelial cells Caco-2 }\end{array}$ & Minocycline & $\begin{array}{l}\text { - } \quad \text { Reduced inflammatory infiltrate, colonic MPO } \\
\text { activity, TNF } \alpha \text {, IL-1 } \beta \text { levels and colonic } \\
\text { iNOS expression } \\
\text { Downregulated IL-8, IL-17, MCP-1, } \\
\text { CINC-1, ICAM-1 } \\
\text { - } \\
\text { Reversed MUC-2 and TFF-3 reduction }\end{array}$ & [66] \\
\hline $\begin{array}{l}\text { - } \quad \text { G. Lahat et al. } \\
\text { - } \quad \text { E. Becker et al. }\end{array}$ & - $\quad$ TNBS-induced colitis in BALB/c mice & $\begin{array}{ll}\text { - } & \text { Ciprofloxacin } \\
\text { - } & \text { Metronidazole }\end{array}$ & $\begin{array}{ll}- & \text { Reduced TNF- } \alpha \text {, IL-1 } \beta \text { and IL8 } \\
- & \text { Reduced recruitment of neutrophils } \\
- & \text { Reduced the levels of NFKB } \\
- & \text { Anti-inflammatory profile in Tregs after treatment; } \\
\text { in naive T-cells observed only after the } \\
\text { recovery period }\end{array}$ & {$[69,70]$} \\
\hline S. Fiorucci et al. & TNBS-induced colitis in BALB/c mice & Rifaximin & $\begin{array}{ll}- & \text { Decreased colonic IL-2, IL-12, IFN- } \alpha \text { and TNF- } \beta \\
\text { - } & \text { Reduced colon MPO activity }\end{array}$ & [71] \\
\hline \multicolumn{5}{|l|}{ Probiotics and LBPS } \\
\hline - $\quad$ M. Bermudez-Brito et al. & - Wild-type Balb/c mice & L. plantarum WCFS1 & $\begin{array}{l}\text { - Polarization of antigen-specific T cell response } \\
\text { towards Th1, Th2, Th17 or Treg. }\end{array}$ & [73] \\
\hline S. M. Lim et al. & $\begin{array}{ll}\text { - } & \text { LPS-stimulated murine } \\
\text { peritoneal macrophages } \\
\text { - } \\
\text { Mice with carrageenan-induced } \\
\text { hind-paw oedema } \\
\text { - } \quad \text { TNBS-induced colitis }\end{array}$ & $\begin{array}{l}\text { - } \quad \text { Lactobacillus } \\
\text { fermentum IM12 }\end{array}$ & $\begin{array}{l}\text { Downregulation of the NF-kB signalling, } \\
\text { suppression of colon shortening, MPO activity as } \\
\text { well as IL-6 and IL-17 levels } \\
\text { Inhibition of the expression of iNOS, COX-2, } \\
\text { activation STAT3 }\end{array}$ & [74] \\
\hline Q. Zhai et al. & - $\quad$ LPS-treated C57BL/6 mice & - $\quad$ Lactobacillus salivarius & $\begin{array}{l}\text { Reversed LPS-induced alterations in gut barrier } \\
\text { function, colonic histopathology, Treg/Th17 } \\
\text { balance, colonic immunomodulatory indicators }\end{array}$ & [75] \\
\hline S. E. Jang et al. & TNBS-induced colitis in C57BL/6 mice & $\begin{array}{ll}- & \text { Bifidobacterium } \\
\text { longum LC67 } \\
\text { - } \quad \text { Lactobacillus } \\
\text { plantarum LC27 }\end{array}$ & $\begin{array}{ll}\text { - } & \text { Inhibition of NF-kB pathway in macrophages and } \\
\text { epithelial cells } & \\
\text { - } & \text { Reduction of Enterobacteriaceae, particularly } \\
\text { Escherichia coli and gut microbiota LPS levels } \\
\text { - } \quad \text { Increased lactobacilli and bifidobacteria } \\
\text { - Inhibition of Th17 cell differentiation and } \\
\text { ROR } \gamma \text { t expression } \\
\text { - Enhanced Treg differentiation and } \\
\text { Foxp3 expression } \\
\text { - } \quad \text { Restoration of the suppressed TJP expression } \\
\text { Increased IL-10 expression }\end{array}$ & [76] \\
\hline
\end{tabular}


Table 1. Cont.

\begin{tabular}{|c|c|c|c|c|}
\hline Authors & Model/Study Case & Treatment & Outcomes & References \\
\hline L. Zhou et al. & DSS-induced colitis in BALB/c mice & Bifidobacterium infantis & $\begin{array}{l}\text { - Increased weight, decreased DAI and histological } \\
\text { damage scores } \\
\text { - } \\
\text { Increased protein expression of Foxp3, PD-L1, as } \\
\text { well as IL-10 and TGF- } \beta 1\end{array}$ & [77] \\
\hline $\begin{array}{l}\text { A. Steimle et al. } \\
\text { A. Rodríguez-Nogales et al. }\end{array}$ & $\begin{array}{l}\text { - } \quad \text { WT C57BL/6 and TLR5-deficient animals as } \\
\text { well as BMCM, C57BL/6N (WT) and Tlr5-/- } \\
\text { mice treated with DSS } \\
\text { - } \\
\text { DSS-treated C57BL/6J mice }\end{array}$ & $\begin{array}{ll}\text { - } & \text { Escherichia coli nissle } \\
\text { EcN } \Delta \text { fli) } \\
\text { - } \\
\text { Escherichia coli Nissle } 1917\end{array}$ & $\begin{array}{ll}\text { - } & \text { Activation of TLR-5, resulting in IL-22-mediated } \\
\text { protection against colitis }\end{array}$ & {$[78,79]$} \\
\hline $\begin{array}{ll}\text { - } & \text { R. Mariman et al. } \\
\text { - } & \text { T. Mimura et al. }\end{array}$ & $\begin{array}{ll}\text { - } & \text { Healthy BALB/c and C57BL/6 mice } \\
\text { - } & \text { IBD Patients }\end{array}$ & VSL\#3 & $\begin{array}{ll}\text { - } & \text { Downregulated Il13 and Eosinophil peroxidase } \\
\text { - } & \text { Upregulated Il12rb1 Cxcr5, Cxcr3, Cxc110 in } \\
& \text { BALB/c mice } \\
- & \text { Increased B cells } \\
- & \text { Decreased T cells } \\
- & \text { Increase cluster of differentiation (CD) 11c(+) cells } \\
- & \begin{array}{l}\text { Increased frequencies of Th17 and Treg in } \\
\text { the MLNs }\end{array} \\
-\quad & \begin{array}{l}\text { Maintained remission at one year in the } 85 \% \\
\text { of patients }\end{array} \\
\text { - High IBDQ score }\end{array}$ & {$[80,81]$} \\
\hline Zhou, H. et al. & - $\quad$ DSS-induced colitis BALB/c mice & Saccharomyces boulardii & $\begin{array}{ll}\text { - } & \text { Reduced body weight loss, DAI and } \\
\text { histological score } \\
\text { - } & \text { Reduced EMT and decreased expression of VEGF }\end{array}$ & [82] \\
\hline \multicolumn{5}{|l|}{ Prebiotics } \\
\hline - $\quad$ K. Ishisono et al. & $\begin{array}{l}\text { TNBS- or DSS-induced colitis in } \\
\text { C57BL/6 mice }\end{array}$ & - $\quad$ Pectin & $\begin{array}{ll}\text { - } & \text { Decreased colonic IL- } 1 \beta \text { and IL-6 levels } \\
\text { - } & \text { Increased faecal concentration of propionic acid }\end{array}$ & [83] \\
\hline Grabinger T. et al. & B6.129P2-Il10tm1Cgn/J mice & 2-fucosyllactose & $\begin{array}{ll}\text { - } & \text { Reduced histological scores, colon shortening } \\
\text { - } & \text { Decreased IL- } \beta \text { and IL- } 6 \text { expression } \\
\text { - } & \text { Increased TGF- } \beta \text { and occludin expression } \\
\text { - } & \text { Expansion of the commensal Ruminococcus gnavus, } \\
\text { accompanied by an enhanced caecal concentration } \\
\text { of propionate }\end{array}$ & [84] \\
\hline
\end{tabular}


Table 1. Cont

\begin{tabular}{|c|c|c|c|c|}
\hline Authors & Model/Study Case & Treatment & Outcomes & References \\
\hline $\begin{array}{ll}\text { - } & \text { S. Kanwal et al. } \\
\text { - } & \text { S. Kanwal et al. }\end{array}$ & $\begin{array}{l}\text { - } \quad \text { BALB/c mice treated with clindamycin } \\
\text { and metronidazole } \\
\text { - } \quad \text { DSS-induced colitis BALB/c mice }\end{array}$ & Dictyophora indusiate & $\begin{array}{ll}\text { - } & \text { Reduced pathogenic bacteria (Enterococcus, } \\
& \text { Bacteroides and Proteobacteria) } \\
\text { - } & \text { Increasing beneficial bacteria (Lactobacillaceae and } \\
& \text { Ruminococaceae) } \\
- & \text { Decreased TNF- } \alpha, \text { IL-6, and IL-1 } \beta \text { levels } \\
- & \text { Increased expression of TJP (claudin-1, occludin, } \\
\text { and zonula occludens-1) } \\
-\quad & \text { Alleviated clinical, histological symptoms of colitis } \\
- & \text { Reduce MPO levels, NO activity } \\
- & \text { Elevated T-SOD levels } \\
- & \text { Reduced TNF- } \alpha, \text { IFN- } \gamma, \text { IL-1 } \beta, \text { IL-6, and IL-17 }\end{array}$ & {$[85,86]$} \\
\hline $\begin{array}{l}\text { C. Diling et al. } \\
\text { Y. Ren et al. }\end{array}$ & $\begin{array}{l}\text { - } \quad \text { TNBS-induced colitis Sprague-Dawley rats } \\
\text { and Kunming mice } \\
\text { - } \quad \text { DSS-induced colitis C57BL/6 mice }\end{array}$ & - $\quad$ Hericium erinaceus & $\begin{array}{ll}- & \text { Normalization of IL1 } \alpha, \text { IL-2, IL-8, IL-10, IL-11, } \\
& \text { IL-12, TNF- }- \text {, TNF- } \alpha \text {, VGEF, MIP- } \alpha \text {, M-CSF and } \\
& \text { MPO levels } \\
- & \text { Increased Foxp3- and IL-10- positive cells } \\
- & \text { Reduced TNF- } \alpha \text { and NF-kB p65- positive cells } \\
- & \text { Reduced proinflammatory microbes } \\
1 . & \text { Enriched anti-inflammatory microbes } \\
- & \text { Downregulated NO, MDA, T-SOD and MPO } \\
- & \text { Reduced IL-6, IL-1 } \beta, \text { TNF- } \alpha, \text { COX-2 and iNOS }\end{array}$ & {$[87,88]$} \\
\hline $\begin{array}{ll}-\quad & \text { R. Li, et al. } \\
\text { - } & \text { R. Li, et al. }\end{array}$ & - $\quad$ DSS-induced colitis C57BL/6J mice & $\begin{array}{l}\text { Muscadine grape (Vitis } \\
\text { rotundifolia) or } \\
\text { wine phytochemicals } \\
\text { Whole muscadine grapes } \\
\text { (FMG) or dealcoholized } \\
\text { muscadine wine (DMW) }\end{array}$ & $\begin{array}{ll}\text { - } & \text { Decreased MPO activity, IL-1 } \beta, \text { IL-6, and TNF- } \alpha \\
\text { - } & \text { levels in colon } \\
\text { Down-regulated NF-kB pathway by inhibiting the } \\
\text { - } \\
\text { - Inosphorylation and degradation of IkB } \\
\text { - } \quad \text { Increased fecal IgA and mucin } 2 \\
\text { Decreased relative abundance of Clostridium and } \\
\text { Akkermansia } \\
\text { - Increased abundances of Roseburia, Anaerotruncus, } \\
\text { and Coprococcus }\end{array}$ & {$[89,90]$} \\
\hline \multicolumn{5}{|l|}{ Synbiotics } \\
\hline T. Shinde et al. & - $\quad$ DSS-induced colitis in C57BL/6J mice & 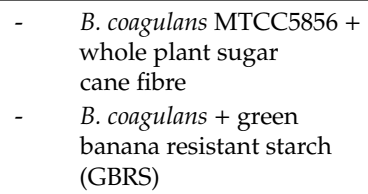 & $\begin{array}{ll}\text { - } & \text { Ameliorated DAI and histological score } \\
\text { - } & \text { Preserved TJP expression } \\
\text { - } & \text { Restored serum IL-1 } \beta, \text { IL-10, and C-reactive } \\
& \text { protein levels } \\
\text { - } & \text { Increase of the SCFA }\end{array}$ & {$[91,92]$} \\
\hline
\end{tabular}


Table 1. Cont.

\begin{tabular}{|c|c|c|c|c|}
\hline Authors & Model/Study Case & Treatment & Outcomes & References \\
\hline H. K. Altun, et al. & - UC patients with mild-to-moderate activity & 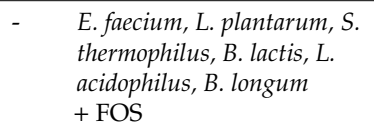 & $\begin{array}{ll}\text { - } & \text { Ameliorated disease status } \\
\text { - } & \text { Significant reduction of systemic inflammation } \\
\text { (serum CRP levels) }\end{array}$ & [93] \\
\hline \multicolumn{5}{|l|}{ Postbiotics } \\
\hline - $\quad$ Tsilingiri K, et al. & $\begin{array}{l}\text { Organ culture system of human healthy and } \\
\text { IBD intestinal mucosa }\end{array}$ & $\begin{array}{l}\text { - Lactobacillus } \\
\text { paracasei supernatant }\end{array}$ & $\begin{array}{l}\text { Reduced TNF- } \alpha \text { production and most of the } \\
\text { cytokines and chemokines involved in the } \\
\text { pathology of IBD including CCL4, CCL2, IFNy } \\
\text { and IL23p40. }\end{array}$ & [94] \\
\hline $\begin{array}{l}\text { F. Yan et al. } \\
\text { X. Shen et al. }\end{array}$ & $\begin{array}{l}\text { - Young adult mouse colon (YAMC) epithelial } \\
\text { cells or kinase suppressor of Ras-1 knockout } \\
\text { (KSRI-/-) mouse colon epithelial (MCE) cells } \\
\text { TNBS and DSS-induced colitis wild-type } \\
\text { C57BL/6 mice }\end{array}$ & $\begin{array}{ll}\text { - } & \text { Lactobacillus rhamnosus } \\
\text { GG-derived protein p40 }\end{array}$ & 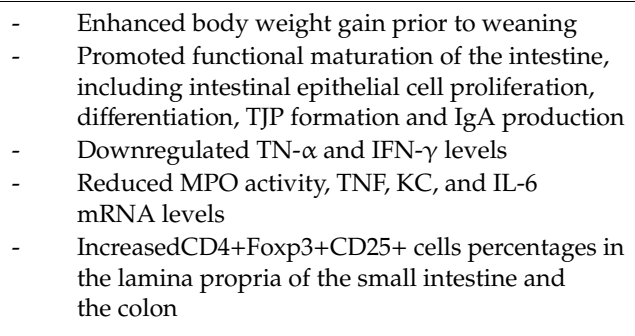 & {$[95-98]$} \\
\hline W. I. Izuddin, et al. & - $\quad$ Lambs & $\begin{array}{ll}\text { - } & \text { Lactobacillus } \\
& \text { plantarum RG14 }\end{array}$ & $\begin{array}{ll}\text { - } & \text { Decreased leukocyte, lymphocyte, basophil, } \\
\text { neutrophil and platelets count } \\
\text { - } & \text { Increased IL-6 mRNA } \\
\text { - } & \text { Decreased IL-1 } \beta, \text { IL-10, TNF mRNA levels } \\
\text { - } & \text { Upregulated TJP-1, CLDN-1 and CLDN-4 } \\
\text { mRNA levels }\end{array}$ & [99] \\
\hline Q. Ren et al. & - $\quad$ DSS-induced colitis C57BL6/J mice & $\begin{array}{l}\text { Conjugated linolenic acid } \\
\text { (CLNA) isolated from } \\
\text { Lactobacillus } \\
\text { plantarum ZS2058) }\end{array}$ & 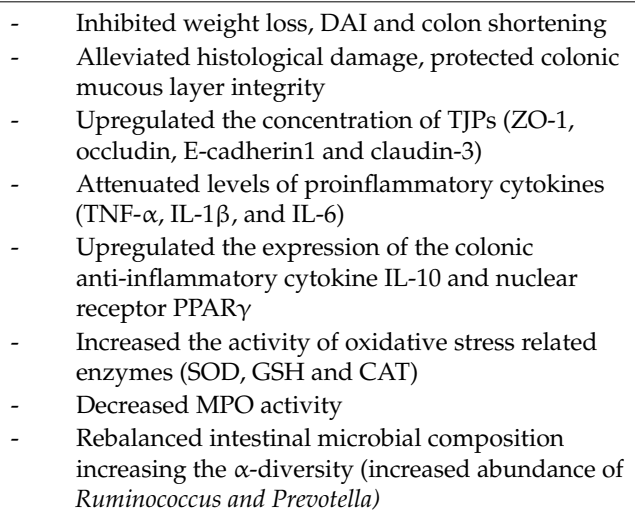 & [100] \\
\hline
\end{tabular}


Table 1. Cont.

\begin{tabular}{|c|c|c|c|c|c|}
\hline & Authors & Model/Study Case & Treatment & Outcomes & References \\
\hline - & L. Van den Bossche et al. & DSS-induced colitis C57Bl/6J mice & $\begin{array}{l}\text { - Ursodeoxycholic acid } \\
\text { (UDCA) and its taurine } \\
\text { (TUDCA) or glycine } \\
\text { conjugates (GUDCA) }\end{array}$ & $\begin{array}{ll}\text { - } & \text { Reduced body weight loss, colonic shortening, } \\
\text { and expression of inflammatory chemokines and } \\
\text { cytokines, such as CXCL1, G-CSF, and IL-6 }\end{array}$ & [101] \\
\hline - & L. Zhou et al. & $\begin{array}{l}\text { - } \quad \text { TNBS-induced colitis C57BL/6J mice and } \\
\text { Sprague-Dawley (SD) rats }\end{array}$ & $\begin{array}{l}\text { - } \quad \begin{array}{l}\text { Butyrate produced by } F . \\
\text { prausnitzii) }\end{array}\end{array}$ & $\begin{array}{ll}- & \text { Maintaining of Th17/Treg balance } \\
\text { - } & \text { Inhibited IL-6/signal transducer and the } \\
\text { STAT3/IL-17 pathway } \\
\text { - } & \text { Promoted Foxp3 by targeting HDAC1 }\end{array}$ & [102] \\
\hline & R. Simeoli et al. & DSS-induced colitis in BALB/c mice & $\begin{array}{l}\text { - } \\
\text { N-(1-carbamoyl-2-phenylethy } \\
\text { butyramide (FBA) } \\
-\end{array}$ & 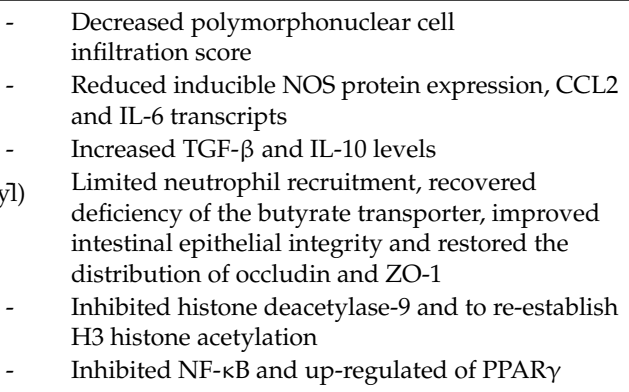 & [103] \\
\hline & Z. Zha et al. & DSS-induced in C57BL/6 mice & $\begin{array}{l}\text { - } \quad \begin{array}{l}\text { Xylan butyrate ester } \\
\text { (XylB) }\end{array}\end{array}$ & $\begin{array}{ll}\text { - } & \text { Reversed the imbalance between IL-1 } \beta, \text { TNF- } \alpha, \\
\text { IL-17A and IL-10 } \\
\text { Decreased relative abundance of Oscillibacter, } \\
\text { Ruminococcaceae UCG-009, Erysipelatoclostridium, } \\
\text { and Defluviitaleaceae UCG-01 } \\
\text { Increased butyrate content } \\
\text { - } & \text { Upregulated G-protein coupled receptor 109A } \\
\text { protein expression } \\
\text { - } & \text { Inhibited HDAC activity } \\
\text { Activated autophagy pathway and inhibited } \\
\text { NF-kB }\end{array}$ & [104] \\
\hline & S. Facchin et al. & - $\quad$ IBD patients & $\begin{array}{l}\text { Microencapsulated form } \\
\text { of sodium butyrate (MSB) }\end{array}$ & $\begin{array}{l}\text { - Increased SCFA-producing bacteria (Butyricicoccus } \\
\text { and Subdoligranulum in CD patients; } \\
\text { Lachnospiraceae in UC patients) } \\
\text { - } \\
\text { Reduction of calprotectin levels }\end{array}$ & [105] \\
\hline
\end{tabular}


Table 1. Cont

\begin{tabular}{|c|c|c|c|c|}
\hline Authors & Model/Study Case & Treatment & Outcomes & References \\
\hline \multicolumn{5}{|l|}{ Faecal Microbiota Transplantation } \\
\hline C. Burrello et al. & $\begin{array}{l}\text { - } \quad \text { DSS-induced acute experimental colitis in } \\
\text { C57BL/6 mice } \\
\text { - DSS-induced chronic experimental colitis in } \\
\text { C57BL/6 mice }\end{array}$ & $\begin{array}{l}\text { FMT by oral gavage of } \\
\text { mucus and faeces from } \\
\text { donor B6 mice }\end{array}$ & $\begin{array}{ll}\text { - } & \text { Decreased levels of pro-inflammatory cytokine } \\
\text { such as TNF, IL1 } \beta \text { and IFN } \gamma \\
\text { - }\end{array}$ & {$[106,107]$} \\
\hline - V. Jacob et al. & - $\quad$ UC patients' mucosal biopsies & FMT by colonoscopy & $\begin{array}{ll}- & \text { Reduced Treg numbers } \\
- & \text { Reduced IFN } \gamma \\
- & \text { No differences in IL-4, IL-17, IL-22 or Th17 }\end{array}$ & [108] \\
\hline - $\quad$ STOP-Colitis study & - $\quad$ UC patients & $\begin{array}{l}\text { FMT by colonic route and } \\
\text { nasogastric tube }\end{array}$ & - $\quad \mathrm{TBD}$ & [109] \\
\hline - $\quad$ FMTFUC study & - UC patients & FMT by gastroscopy & $\begin{array}{l}\text { - Decreased clinical index scores for diarrhea, } \\
\text { abdominal pain, and blood stool } \\
\text { - Normalized gut microbiota composition }\end{array}$ & [110] \\
\hline - $\quad$ IMPACT-Crohn study & - $\quad$ CD patients & FMT by colonoscopy & $\begin{array}{ll}\text { - } & \text { Crohn's Disease Endoscopic Index of } \\
\text { Severity decreased } \\
\text { - } & \text { Increased alpha diversity } \\
\text { - } & \text { Higher colonization by donor microbiota was } \\
\text { associated with maintenance of remission }\end{array}$ & [111] \\
\hline
\end{tabular}




\subsection{Probiotics and LBPS}

Probiotics are living microorganisms that can be used as non-pharmacological methods to promote gut health and potentially modulate dysbiosis in IBD [112]. Their mechanism of action is largely strain-dependent, although their beneficial effects mostly depend on their metabolisms and metabolic by-products (e.g., SCFAs, bacteriocins, hydroperoxides, secondary bile acids, and lactic acids) capable to promote the release of cellular components in the gut environment which in turn can activate immune responses [113]. Probiotics may be sampled by M cells in the Peyer's patches [114] and modulate the activity of APC [115]. The interaction between probiotics and DCs may influence the subsequent antigen-specific T cell response towards Th1, Th2, Th17 or Treg cells, although some strains of lactobacilli (L. plantarum) regulates Treg frequency and DCs activation even in the absence of M-dependent sampling [73]. Different strains of Lactobacillus and Bifidobacterium showed significant capability to reduce pro-inflammatory IL-6 and IL-17 levels [74], to restore the Treg/Th17 balance [75] via inhibition of the NF- $\mathrm{KB}$ signalling pathway in macrophages and epithelial cells and to control the overgrowth of pathobionts belonging to Enterobacteriaceae [76,77]. E. coli Nissle 1917 (EcN), can colonize the intestine and perform several documented protective functions being successfully used to extend remission phases in IBD patients in clinical routine [116]. EcN flagellin is able to induce a strong activation of TLR-5 and therefore to enhance IL-22 production, a cytokine mediating epithelial reconstitution [78] and promoting intestinal immune homeostasis via Treg expansion [79]. In addition, probiotics can indirectly affect pathobionts colonization via host's PPAR- $\gamma$ signalling [117]. VSL\#3 is a high-concentration probiotic preparation of eight live freeze-dried bacterial probiotic species including lactobacilli (L. casei, L. plantarum, L. acidophilus, and L. delbrueckii subsp. bulgaricus), bifidobacteria (B. longum, B. breve, and B. infantis), and Streptococcus salivarius subsp. [118], capable to regulate microbiota composition [119] by reducing luminal oxygen and inhibiting aerobic Enterobacteriaceae and immune responses [80]. The VSL\#3 treatment determines anti-inflammatory effects in experimental colitis, as evidenced by reduced disease activity index (DAI) score, histological activity index (HAI) score and myeloperoxidase (MPO) activity [120]. Furthermore, in different randomized, double-blind, placebo-controlled trials the use of VSL\#3 in UC patients showed significant effects in terms of clinical remission and clinical response during active UC with no side-effects [81,121]. However, the efficacy of probiotics in IBD remains uncertain, since different meta-analyses showed that there were no significant differences of remission, relapse, and complication rate between probiotics and placebo group, thus, more evidences from randomized clinical trials (RCTs) are required [122,123].

Not only bacteria but also fungi are used as probiotics. Saccharomyces boulardii is a well characterized probiotic yeast often used to alleviate gastrointestinal (GI) tract disorders [82]. Nevertheless, probiotics effects are often transient and limited in most IBD subsets because of i) inability to replace/restore the microbial species depleted in IBD patients [124], ii) colonization resistance, since individual immunological status and mucosal microbial features are associated with probiotics persistence [125], iii) treatment timing and proper delivery mode [126]. Therefore, a new era in probiotic research is addressing specific patient's needs towards the comprehension of a wider microorganism's range with potential health benefits. These organisms are known as live biotherapeutic products (LBPs). LBPs conform to the normal definition of probiotics but they differ from them because they also include genetically modified microorganisms (GMMs) and because their use is addressed under a pharmacological point-of-view [126]. Despite remaining safety and environmental concerns, GMM can be used as vehicle for delivering a range of anti-inflammatory molecules such as anti-TNF, IL-10-, IL-27-, elafin-secreting Lactococcus species [127] and efficiently alleviate mucosal inflammation by promoting a homeostatic immunologic profile.

\subsection{Prebiotic Diets and Synbiotics}

Prebiotics are non-digestible dietary compounds that stimulate the growth and activity of probiotics, conferring a competitive advantage to commensal bacteria capable of metabolizing these substrates or by increasing the production of beneficial metabolic products that result from their fermentation [3]. 
Since prebiotics are resistant to hydrolysis by human alimentary tract enzymes, they can be fermented by colonic anaerobic bacteria to produce metabolites important for host physiology such as SCFA [128,129]. A high-fiber diet has been reported to protect against the development of experimental intestinal inflammation [130] and to directly interact with host cells modulating immune responses [131]. High doses of pectin decreases the expression of colonic pro-inflammatory mediators, including IL-1 $\beta$ and IL-6, [83]. Oral supplementation with 2-fucosyllactose significantly decreased the severity of colitis in IL- $10^{-/-}$mice, reducing the expression of IL- $1 \beta$ and IL- 6 and increasing TGF- $\beta$ expression and expansion of the propionate-producing commensal Ruminococcus gnavus [84]. Dictyophora indusiate polysaccharides (DIP) demonstrated to have therapeutic potential in the restoration of antibiotic-induced gut dysbiosis and inflammatory responses in BALB/c mice [85] and in DSS-induced colitis mice [86]. Polysaccharide, alcoholic and whole extracts of the edible mushroom Hericium erinaceus have been reported to reduce the abundance of pathobionts and to promote the enrichment of some health-promoting bacteria, (i.e., Bifidobacterium, Parabacteroides, Lactobacillus, Coprococcus) [87]. Furthermore, these extracts reduced the levels of serum IL1- $\alpha$, IL-2, IL-8, IL-10, IL-11, IL-12, TNF- $\gamma$, TNF- $\alpha$, vascular endothelial growth factor (VGEF), macrophage inflammatory protein- $\alpha$ (MIP- $\alpha$ ), macrophage colony-stimulating factor (M-CSF) and MPO as well as the proportion of TNF- $\alpha$ and NF- $k B$ p65- positive cells and Tregs increased [88]. Also grape polyphenols showed prebiotic activities, promoting the growth of Bifidobacerium and Lactobacillus while inhibiting that of Clostridium histolyticum [132]. Muscadine grapes or wine phytochemicals are capable to decrease MPO activity as well as colonic levels of IL-1 $\beta$, IL-6, and TNF- $\alpha$ in experimental DSS-colitis [89]. Whole muscadine grapes (FMG) or dealcoholized muscadine wine (DMW) supplementation in colitic animals decreases the relative abundance of Clostridium and Akkermansia, increases abundances of Roseburia, Anaerotruncus, and Coprococcus, resulting in higher faecal levels of butyric acid, acetic acid and fecal IgA, suggesting a more robust activation of the adaptive immune system [90]. The combination of both prebiotics and probiotics, called "synbiotic", can provide beneficial effects to the host and improve the viability of its constituents [133]. Given that IBD patients harbour less health-promoting bacteria, administration of synbiotics may improve treatment with probiotics or LBPs. B. coagulans MTCC585, in combination with the prebiotic whole plant sugar cane fibre (PSCF), has synergistic effects in colitic mice being sufficient to modulate serum IL-1 $\beta$, IL-10, and CRP levels and raising the SCFA profile [91]. Similarly, the synbiotic B. coagulans combination with the green banana resistant starch (GBRS) demonstrated to prevent intestinal inflammation through the suppression of IL-1 $\beta$ and to increase IL-10 levels [92]. A recent randomized placebo-controlled study evaluated the efficacy of a synbiotic therapy in mild-to-moderately active UC by administrating six probiotic strains with the prebiotic fructo-oligosaccharide (FOS). The study showed an amelioration of the disease status of the synbiotic treated UC patients and a significant reduction of systemic inflammation as measured by serum CRP levels. These results support the use of synbiotics as an effective strategy to prevent the exacerbation of the disease in patients with mild-to-moderately active UC [93]. Nevertheless, although prebiotics have an excellent safety profile, they have been associated with symptoms of dose-dependent abdominal pain, flatulence, bloating, and diarrhea [134]; therefore, insoluble fibre intake is discouraged in the case of significant intestinal stenosis in IBD patients [135].

\subsection{Postbiotics}

Bacterial viability is not always required to promote health-promoting effects, leading to the hypothesis that bioactive compounds derived from probiotics fermentation processes, the so-called postbiotics, might suffice to promote a healthy status [136] and be a safer alternative for patient treatments. Postbiotics comprise SCFAs, enzymes, peptides, teichoic acids, peptidoglycan-derived muropeptides, endo- and exo-polysaccharides, cell surface proteins, vitamins, plasmalogens, and organic acids [137] and, in the majority of cases, are derived from Lactobacillus and Bifidobacterium strains, but also from Streptococcus and Faecalibacterium species [94]. The mechanisms of action of postbiotics are not well characterized, but it has been hypothesised that they may influence the host cellular pathways involving proliferation, differentiation, migration and cellular death as well as the maturation/function of mucosal 
and systemic immunity [138]. The use of viable biotherapeutic products might cause problems related to safety for human use. Indeed, the use of L. plantarum NCIMB8826, L. rhamnosus GG (LGG) and L. paracasei B21060 showed deleterious side-effects on inflamed IBD-derived tissues [139,140]. Incubation of IBD-derived organ cultures with $L$. paracasei supernatants resulted instead in a significant reduction in TNF- $\alpha$ production as well as in most of the cytokines and chemokines involved in the pathology of IBD, including chemokine (C-C motif) ligands (CCL)-4, CCL2, IFN- $\gamma$ and IL23p40 [140]. Similarly, the spent medium of L. rhamnosus GG (LGG) promoted IgA secretion decreasing the susceptibility to intestinal injury and colitis in adult mice [95], a mechanism mediated by the L. rhamnosus GG protein p40 [96-98]. Postbiotics from L. plantarum RG14 also modulated leukocyte, lymphocyte, basophil, neutrophil and platelets counts, increased IL-6 mRNA and decreased of IL-1 $\beta$, IL-10, TNF mRNA levels [99]. Conjugated linolenic acids (CLNA), a positional and geometric isomer of unsaturated fatty acids, obtained from the fermentation of Lactobacillus plantarum ZS2058 are also potential postbiotic agents. The isomers of c9, $\mathrm{t} 11$, c15-CLNA (CLNA-1) and $\mathrm{t} 9$, $\mathrm{t} 11, \mathrm{c} 15$-CLNA (CLNA-2) significantly attenuated the level of MPO and of proinflammatory cytokines (TNF- $\alpha$, IL-1 $\beta$, and IL-6) while upregulated the expression of IL-10 and the nuclear receptor PPAR $\gamma$ [100]. Oral administration of secondary bile acid ursodeoxycholic acid (UDCA) and its taurine (TUDCA) or glycine conjugates (GUDCA) to colitic mice were also shown to control intestinal dysbiosis and the expression of inflammatory chemokines and cytokines, such as chemokine (C-X-C motif) ligand 1 (CXCL1), granulocyte colony-stimulating factor (G-CSF), and IL-6. At systemic level, lower levels of CXCL1 and G-CSF, but not IL-6, were detected in the serum of bile acid-treated mice than in that of the placebo-treated group [101]. Peptides derived from Bacteroides fragilis YCH46 (peptide B12) [141] and from probiotic Bifidobacterium longum subsp. longum ATCC15707 (peptide B7) [142-144] can influence the immunoregulatory capacity of human APCs (including B-cells, monocytes, plasmacytoid DCs (pDCs), and conventional DCs (cDCs). Both peptides are capable to increase the pro-inflammatory profile of IBD-derived APC, as demonstrated by the enhanced expression of human leukocyte antigen-DR (HLA-DR) on cDC prompted by peptide B7, which also expanded IL-1 $\beta$ production of B-cells and on $\mathrm{pDC}$ by B12. This phenomenon was not observed in APC derived from healthy individuals, suggesting that differential immune mechanisms between healthy controls and IBD patients may abrogate the immunomodulatory tolerogenic potential of bioactive peptides from the gut microbiota in IBD [145]. In experimental colitis models, butyrate, a SCFA, produced by F. prausnitzii maintained Th17/Treg balance and exerted significant anti-inflammatory effects via inhibition of the IL-6/signal transducer, the STAT3/IL-17 pathway and promoted Foxp3 expression by targeting histone deacetylase 1 (HDAC1) [102]. Butyrate-derivates are currently studied for oral administration to patients such as the N-(1-carbamoyl-2-phenylethyl) butyramide (FBA) which showed similar health-promoting activities compared to butyrate [103]. Xylan butyrate ester (XylB) is a butyrate-releasing polysaccharide derivative. XylB treatments reversed the imbalance between pro(IL-1 $\beta$, TNF- $\alpha$, and IL-17A) and anti-inflammatory (IL-10) cytokines in experimental colitis. Moreover, XylB rebalanced the gut microbiota and significantly decreased the relative abundance of the genera Oscillibacter, Ruminococcaceae, Erysipelatoclostridium, and Defluviitaleaceae [104]. The use of postbiotics has been tested also in a prospective-randomised-placebo-controlled study with IBD patients. The effect of a microencapsulated form of sodium butyrate (MSB) was evaluated. MSB induced significant changes in the gut microbiota of IBD patients by increasing the abundance of SFCA-producing bacteria. This study showed that MSB supplementation produced a mimicking prebiotic effect increasing the production of endogenous and physiological SCFAs with a marked improvement of quality of life and reduction of inflammatory markers [105].

\subsection{Faecal Microbiota Transplantation}

Gut microbiota manipulation through faecal microbiota transplantation (FMT), i.e., the procedure of transferring the microbial ecology of a healthy donor into a patient to treat microbial dysbiosis [146], is gaining great attention by the medical community. Currently, FMT has proved to be highly successful in treating recurrent and antibiotic refractory Clostridiodes difficile (C. difficile) infection (CDI), with cure 
rates approaching 90\% [147]. Nevertheless, while it is clear that in CDI FMT efficiently eliminates the pathogen and its virulence factors, [148], less is known on the mechanisms behind the therapeutic effects of FMT in IBD. We showed that therapeutic FMT administered during acute experimental colitis could directly modulate both innate and adaptive mucosal immune responses towards the control of intestinal inflammation. Therapeutic FMT not only is able to reduce colonic inflammation, as demonstrated by decreased levels of the pro-inflammatory cytokines TNF, IL1- $\beta$ and IFN- $\gamma$, but also to initiate the restoration of intestinal homeostasis through the simultaneous activation of different immune-mediated pathways. Indeed, higher amounts of colonic IL-10 as well as increased frequencies of IL-10-producing APC and CD4+ T and iNKT cells were observed in FMT-treated mice as compared to DSS-treated mice. Furthermore, FMT treatments reduced the ability of DCs, monocytes and macrophages to present major histocompatibility complex (MHC-II) dependent bacterial antigens to colonic T cells. The beneficial effects of FMT during intestinal inflammation were also associated with a reshuffling of the intestinal microbial communities towards restoration of functional normobiosis [106]. Furthermore, we also showed that therapeutic FMT administration in the context of a chronic experimental colitis setting, a condition more similar to that of IBD patients, stably decreased colonic inflammation by modulating the expression of pro-inflammatory genes, such as Ifng, Tnf, Il1b, Il-17, and Il-6 [107]. Mice receiving FMT displayed a lower proportion of CD4+ T and CD8+ T cells expressing the cytotoxicity-associated molecule CD107a as well as reduction of colonic MHC-II-expressing professional APCs [107]. Recently, it was also examined the impact of transferring the gut microbiota from healthy or IBD donors into GF mice to determine the homeostatic intestinal $\mathrm{T}$ cell response to each microbiota. The transfer of IBD microbiota into GF mice increased the numbers of intestinal Th17 cells and Th2 cells and decreased numbers of ROR $\gamma \mathrm{t}+$ Treg cells. These data further support the concept that only an eubiotic core ecology is able to induce or maintain an anti-inflammatory polarized mucosal immune response [149]. Most of the available data regarding FMT in IBD come from studies in UC patients [150]. In a single-centre, prospective, open-label pilot study was tested the impact of preparation and donor characteristics on FMT success. Immune cell profiling was performed on mucosal biopsies before and after FMT to assess its impact on mucosal T cell immunity. Analysis of CD4+ T cell cytokine production revealed a significant reduction in IFN- $\gamma$ in Tregs at week 4 compared to time of transplant, however no difference in IL-4, IL-17, IL-22 or Th17 was reported [108]. Moreover, specific members of the gut mycobiota can play a protective function in the gut [151]. Getting a better knowledge on host response to these organisms might harbour potential predictive markers on the outcome of microbiome-based therapies and should be further explored in future FMT trials [152].

Different RCTs have been performed so far in IBD patients, with those performed in mild-moderate UC giving the best results [153-156] while few data are available on CD patients [150]. All these RCTs demonstrated efficacy of FMT over placebo, although there were many inconsistencies in some studies where UC patients receiving FMT from healthy donors and autologous FMT did not show statistically significant difference in clinical remission $[154,156]$.

Since almost all studies performed to date have assessed the role of FMT in remission induction for IBD, with a paucity of literature on the potential of FMT as a maintenance therapy, at present several clinical trials are evaluating the FMT influence on the immune system and clinical outcomes. The STOP-Colitis study [109] is evaluating not only the efficacy and safety of FMT in UC patients, but also the colonic immune profile of recipients before and after FMT. Furthermore, the Chinese FMTFUC study [110] will evaluate local and systemic inflammatory markers in UC FMT-treated patients. Finally, the University of Vermont Medical Center [NCT02390726] is assessing inflammatory markers pre- and post-FMT as well as changes in the host immune response via measurement of both mucosal and peripheral T-cells populations (Th1, Th2, Th17) using mucosal biopsies and blood samples respectively [157].

Unfortunately, at present, most of the available data regarding FMT in IBD is in UC patients and no RCTs results are available for CD patients, although the IMPACT-Crohn study [111] is assessing the 
impact of FMT on CD analysing also circulating and colonic lymphocyte levels in comparison with sham transplantation.

\section{Conclusions and Future Perspectives}

IBD onset is caused by dysregulated immune responses to the gut microbiota in genetically susceptible hosts [158]. Although, the clinical heterogeneity of IBD patients as well as their unique gut microbiota features may reduce the efficacy of current treatments, selection of therapeutic targets based on individual's microbiota patterns and immunological profiles will be important for the design of personalised and effective intervention strategies in the near future. To date, IBD patients are treated with standard anti-TNF agents and immunomodulators further supported by probiotics, prebiotics, antibiotics treatments or faecal microbial transplantation on an empiric base. The customization of these different treatments based on the clinical [59] and dysbiotic status of individual patients should be implemented in the current clinical practice to promote homeostatic immune responses in order to manage IBD in a more effective, physiologic, and patient-oriented manner.

Author Contributions: Writing—original draft preparation C.A., F.P.; writing-review and editing F.S., M.F., F.C.; supervision and funding acquisition F.F. All authors have read and agreed to the published version of the manuscript.

Funding: This work was made possible through grants of Italy's Ministry of Health to FF (GR-2016-02361741).

Conflicts of Interest: The authors declare no conflict of interest.

\section{References}

1. Neurath, M.F. Targeting immune cell circuits and trafficking in inflammatory bowel disease. Nat. Immunol. 2019, 20, 970-979. [CrossRef] [PubMed]

2. Graham, D.B.; Xavier, R.J. Pathway paradigms revealed from the genetics of inflammatory bowel disease. Nature 2020, 578, 527-539. [CrossRef] [PubMed]

3. Schirmer, M.; Garner, A.; Vlamakis, H.; Xavier, R.J. Microbial genes and pathways in inflammatory bowel disease. Nat. Rev. Genet. 2019, 17, 497-511. [CrossRef] [PubMed]

4. Lavelle, A.; Sokol, H. Gut microbiota-derived metabolites as key actors in inflammatory bowel disease. Nat. Rev. Gastroenterol. Hepatol. 2020, 1-15. [CrossRef]

5. Xavier, R.J.; Podolsky, D.K. Unravelling the pathogenesis of inflammatory bowel disease. Nature 2007, 448, 427-434. [CrossRef]

6. Gazouli, M.; Dovrolis, N.; Franke, A.; Spyrou, G.M.; Sechi, L.A.; Spyrou, G.M. Differential genetic and functional background in inflammatory bowel disease phenotypes of a Greek population: A systems bioinformatics approach. Gut Pathog. 2019, 11, 31. [CrossRef]

7. Jostins, L.; The International IBD Genetics Consortium (IIBDGC); Ripke, S.; Weersma, R.K.; Duerr, R.H.; McGovern, D.P.; Hui, K.Y.; Lee, J.C.; Schumm, P.; Sharma, Y.; et al. Host-microbe interactions have shaped the genetic architecture of inflammatory bowel disease. Nature 2012, 491, 119-124. [CrossRef]

8. McCole, D.F. IBD candidate genes and intestinal barrier regulation. Inflamm. Bowel Dis. 2014, 20, 1829-1849. [CrossRef]

9. Cadwell, K. Crohn's disease susceptibility gene interactions, a NOD to the newcomer ATG16L1. Gastroenterology 2010, 139, 1448-1450. [CrossRef]

10. Suzuki, M.; Nagaishi, T.; Yamazaki, M.; Onizawa, M.; Watabe, T.; Sakamaki, Y.; Ichinose, S.; Totsuka, M.; Oshima, S.; Okamoto, R.; et al. Myosin Light Chain Kinase Expression Induced via Tumor Necrosis Factor Receptor 2 Signaling in the Epithelial Cells Regulates the Development of Colitis-Associated Carcinogenesis. PLoS ONE 2014, 9, e88369. [CrossRef]

11. Surawicz, C.; Haggitt, R.C.; Husseman, M.; McFarland, L.V. Mucosal biopsy diagnosis of colitis: Acute self-limited colitis and idiopathic inflammatory bowel disease. Gastroenterology 1994, 107, 755-763. [CrossRef]

12. Oshima, S.; Nakamura, T.; Namiki, S.; Okada, E.; Tsuchiya, K.; Okamoto, R.; Yamazaki, M.; Yokota, T.; Aida, M.; Yamaguchi, Y.; et al. Interferon Regulatory Factor 1 (IRF-1) and IRF-2 Distinctively Up-Regulate Gene Expression and Production of Interleukin-7 in Human Intestinal Epithelial Cells. Mol. Cell. Boil. 2004, 24, 6298-6310. [CrossRef] [PubMed] 
13. Wehkamp, J.; Harder, J.; Weichenthal, M.; Schwab, M.; Schäffeler, E.; Schlee, M.; Herrlinger, K.R.; Stallmach, A.; Noack, F.; Fritz, P.; et al. NOD2 (CARD15) mutations in Crohn's disease are associated with diminished mucosal $\alpha$-defensin expression. Gut 2004, 53, 1658-1664. [CrossRef] [PubMed]

14. Jäger, S.; Stange, E.F.; Wehkamp, J. Inflammatory bowel disease: An impaired barrier disease. Langenbecks Archiv für Chirurgie 2012, 398, 1-12. [CrossRef] [PubMed]

15. Cadwell, K.; Patel, K.K.; Komatsu, M.; Virgin, I.H.W.; Stappenbeck, T.S.; Virgin, H.W. A common role for Atg16L1, Atg5, and Atg7 in small intestinal Paneth cells and Crohn's disease. Autophagy 2009, 5, $250-252$. [CrossRef] [PubMed]

16. Okamoto, R.; Watanabe, M. Role of epithelial cells in the pathogenesis and treatment of inflammatory bowel disease. J. Gastroenterol. 2015, 51, 11-21. [CrossRef]

17. Caruso, R.; Lo, B.C.; Nunez, G. Host-microbiota interactions in inflammatory bowel disease. Nat. Rev. Immunol. 2020, 1-16. [CrossRef]

18. Ivanov, I.I.; McKenzie, B.S.; Zhou, L.; Tadokoro, C.E.; Lepelley, A.; Lafaille, J.J.; Cua, D.J.; Littman, D.R. The Orphan Nuclear Receptor ROR $\gamma$ t Directs the Differentiation Program of Proinflammatory IL-17+ T Helper Cells. Cell 2006, 126, 1121-1133. [CrossRef]

19. Langrish, C.L.; Chen, Y.; Blumenschein, W.M.; Mattson, J.; Basham, B.; Sedgwick, J.D.; McClanahan, T.; Kastelein, R.A.; Cua, D.J. IL-23 drives a pathogenic T cell population that induces autoimmune inflammation. J. Exp. Med. 2005, 201, 233-240. [CrossRef]

20. Ivanov, I.I.; Atarashi, K.; Manel, N.; Brodie, E.L.; Shima, T.; Karaoz, U.; Wei, N.; Goldfarb, K.C.; Santee, C.A.; Lynch, S.V.; et al. Induction of Intestinal Th17 Cells by Segmented Filamentous Bacteria. Cell 2009, 139, 485-498. [CrossRef]

21. Yang, Y.; Torchinsky, M.B.; Gobert, M.; Xiong, H.; Xu, M.; Linehan, J.L.; Alonzo, F.; Ng, C.; Chen, A.; Lin, X.; et al. Focused specificity of intestinal TH17 cells towards commensal bacterial antigens. Nature 2014, 510, 152-156. [CrossRef] [PubMed]

22. Nizzoli, G.; Burrello, C.; Cribiù, F.M.; Lovati, G.; Ercoli, G.; Botti, F.; Trombetta, E.; Porretti, L.; Todoerti, K.; Neri, A.; et al. Pathogenicity of In Vivo Generated Intestinal Th17 Lymphocytes is IFN $\gamma$ Dependent. J. Crohns Colitis 2018, 12, 981-992. [CrossRef] [PubMed]

23. Vernero, M.; Astegiano, M.; Ribaldone, D.G. New Onset of Inflammatory Bowel Disease in Three Patients Undergoing IL-17A Inhibitor Secukinumab. Am. J. Gastroenterol. 2019, 114, 179-180. [CrossRef] [PubMed]

24. Fries, W.; Belvedere, A.; Cappello, M.; Orlando, A.; Trifirò, G. Inflammatory Bowel Disease Onset During Secukinumab Treatment: Real Concern or Just an Expression of Dysregulated Immune Response? Clin. Drug Investig. 2019, 39, 799-803. [CrossRef]

25. Moncada, R.R.; Morón, J.M.V.; Feria, M.R.; Justiniano, J.M.H.; Pérez, B.M.; Fernández, M.C.; Ortiz, A.N.; Rubio, V.C.; Manrique, H.P.; Delgado, E.G.; et al. P762 Onset of inflammatory bowel disease during treatment with secukinumab: Can anti-IL-17A be a trigger for inflammatory bowel disease? J. Crohns Colitis 2019, 13, S502. [CrossRef]

26. Yamada, A.; Arakaki, R.; Saito, M.; Tsunematsu, T.; Kudo, Y.; Ishimaru, N. Role of regulatory T cell in the pathogenesis of inflammatory bowel disease. World J. Gastroenterol. 2016, 22, 2195-2205. [CrossRef]

27. Sellon, R.K.; Tonkonogy, S.; Schultz, M.; Dieleman, L.A.; Grenther, W.; Balish, E.; Rennick, D.M.; Sartor, R.B. Resident Enteric Bacteria Are Necessary for Development of Spontaneous Colitis and Immune System Activation in Interleukin-10-Deficient Mice. Infect. Immun. 1998, 66, 5224-5231. [CrossRef]

28. Glocker, E.-O.; Kotlarz, D.; Boztug, K.; Gertz, E.M.; Schäffer, A.A.; Noyan, F.; Perro, M.; Diestelhorst, J.; Allroth, A.; Murugan, D.; et al. Inflammatory bowel disease and mutations affecting the interleukin-10 receptor. New Engl. J. Med. 2009, 361, 2033-2045. [CrossRef]

29. Elson, C.O.; Cong, Y. Host-microbiota interactions in inflammatory bowel disease. Gut Microbes 2012, 3, 332-344. [CrossRef]

30. Atarashi, K.; Tanoue, T.; Shima, T.; Imaoka, A.; Kuwahara, T.; Momose, Y.; Cheng, G.; Yamasaki, S.; Saito, T.; Ohba, Y.; et al. Induction of Colonic Regulatory T Cells by Indigenous Clostridium Species. Science 2010, 331, 337-341. [CrossRef]

31. Momose, Y.; Maruyama, A.; Iwasaki, T.; Miyamoto, Y.; Itoh, K. 16S rRNA gene sequence-based analysis of clostridia related to conversion of germfree mice to the normal state. J. Appl. Microbiol. 2009, 107, $2088-2097$. [CrossRef] [PubMed] 
32. Alameddine, J.; Godefroy, E.; Papargyris, L.; Sarrabayrouse, G.; Tabiasco, J.; Bridonneau, C.; Yazdanbakhsh, K.; Sokol, H.; Altare, F.; Jotereau, F. Faecalibacterium prausnitzii Skews Human DC to Prime IL10-Producing T Cells Through TLR2/6/JNK Signaling and IL-10, IL-27, CD39, and IDO-1 Induction. Front. Immunol. 2019, 10, 143. [CrossRef] [PubMed]

33. Nakagawa, R.; Yoshimura, A. Interaction between gut microbiota and host immune cells. Inflamm. Regen. 2015, 35, 140-147. [CrossRef]

34. Mishima, Y.; Sartor, R.B. Manipulating resident microbiota to enhance regulatory immune function to treat inflammatory bowel diseases. J. Gastroenterol. 2019, 55, 4-14. [CrossRef] [PubMed]

35. Sun, X.; He, S.; Lv, C.; Sun, X.; Wang, J.; Zheng, W.; Wang, D. Analysis of murine and human Treg subsets in inflammatory bowel disease. Mol. Med. Rep. 2017, 16, 2893-2898. [CrossRef]

36. An, D.; Oh, S.F.; Olszak, T.; Neves, J.F.; Avci, F.Y.; Ertürk-Hasdemir, D.; Lu, X.; Zeissig, S.; Blumberg, R.S.; Kasper, D.L. Sphingolipids from a symbiotic microbe regulate homeostasis of host intestinal natural killer $\mathrm{T}$ cells. Cell 2014, 156, 123-133. [CrossRef]

37. Burrello, C.; Garavaglia, F.; Cribiù, F.M.; Ercoli, G.; Bosari, S.; Caprioli, F.; Facciotti, F. Short-term Oral Antibiotics Treatment Promotes Inflammatory Activation of Colonic Invariant Natural Killer T and Conventional CD4+ T Cells. Front. Med. 2018, 5, 21. [CrossRef]

38. Burrello, C.; Pellegrino, G.; Giuffrè, M.R.; Lovati, G.; Magagna, I.; Bertocchi, A.; Cribiù, F.M.; Boggio, F.; Botti, F.; Trombetta, E.; et al. Mucosa-associated microbiota drives pathogenic functions in IBD-derived intestinal iNKT cells. Life Sci. Alliance 2019, 2, e201800229. [CrossRef]

39. Olszak, T.; Neves, J.F.; Dowds, C.M.; Baker, K.; Glickman, J.; Davidson, N.O.; Lin, C.-S.; Jobin, C.; Brand, S.; Sotlar, K.; et al. Protective mucosal immunity mediated by epithelial CD1d and IL-10. Nature 2014, 509, 497-502. [CrossRef]

40. Saubermann, L.J.; Beck, P.; De Jong, Y.P.; Pitman, R.S.; Ryan, M.S.; Kim, H.S.; Snapper, S.; Hagen, S.J.; Kanauchi, O.; Motoki, K.; et al. Activation of natural killer T cells by $\alpha$-galactosylceramide in the presence of CD1d provides protection against colitis in mice. Gastroenterology 2000, 119, 119-128. [CrossRef]

41. Ueno, Y.; Tanaka, S.; Sumii, M.; Miyake, S.; Tazuma, S.; Taniguchi, M.; Yamamura, T.; Chayama, K. Single Dose of OOCH Improves Mucosal T Helper Type 1/T Helper Type 2 Cytokine Balance and Prevents Experimental Colitis in the Presence of V $\alpha 14$ Natural Killer T Cells in Mice. Inflamm. Bowel Dis. 2005, 11, 35-41. [CrossRef] [PubMed]

42. Kim, H.S.; Chung, D.H. IL-9-producing invariant NKT cells protect against DSS-induced colitis in an IL-4-dependent manner. Mucosal Immunol. 2012, 6, 347-357. [CrossRef] [PubMed]

43. Mazmanian, S.K.; Liu, C.H.; Tzianabos, A.O.; Kasper, D.L. An Immunomodulatory Molecule of Symbiotic Bacteria Directs Maturation of the Host Immune System. Cell 2005, 122, 107-118. [CrossRef] [PubMed]

44. Geremia, A.; Arancibia-Cárcamo, C.V.; Fleming, M.P.; Rust, N.; Singh, B.; Mortensen, N.J.; Travis, S.P.; Powrie, F. IL-23-responsive innate lymphoid cells are increased in inflammatory bowel disease. J. Exp. Med. 2011, 208, 1127-1133. [CrossRef] [PubMed]

45. Han, L.; Wang, X.-M.; Di, S.; Gao, Z.; Li, Q.; Wu, H.; Wang, Q.; Zhao, L.; Tong, X. Innate Lymphoid Cells: A Link between the Nervous System and Microbiota in Intestinal Networks. Mediat. Inflamm. 2019, 2019, 1978094. [CrossRef] [PubMed]

46. Sonnenberg, G.F.; Monticelli, L.A.; Elloso, M.M.; Fouser, L.A.; Artis, D. CD4+ Lymphoid Tissue-Inducer Cells Promote Innate Immunity in the Gut. Immunology 2010, 34, 122-134. [CrossRef]

47. Ng, S.C.; Benjamin, J.L.; McCarthy, N.; Hedin, C.; Koutsoumpas, A.; Plamondon, S.; Price, C.L.; Hart, A.L.; Kamm, M.A.; Forbes, A.; et al. Relationship between human intestinal dendritic cells, gut microbiota, and disease activity in Crohn's disease. Inflamm. Bowel Dis. 2011, 17, 2027-2037. [CrossRef]

48. Hart, A.L.; Al-Hassi, H.O.; Rigby, R.; Bell, S.J.; Emmanuel, A.V.; Knight, S.C.; Kamm, M.A.; Stagg, A.J. Characteristics of intestinal dendritic cells in inflammatory bowel diseases. Gastroenterology 2005, 129, 50-65. [CrossRef]

49. Brinkmann, V. Neutrophil Extracellular Traps Kill Bacteria. Science 2004, 303, 1532-1535. [CrossRef]

50. Gupta, S.; Kaplan, M.J. The role of neutrophils and NETosis in autoimmune and renal diseases. Nat. Rev. Nephrol. 2016, 12, 402-413. [CrossRef]

51. DiNallo, V.; Marafini, I.; Di Fusco, D.; Laudisi, F.; Franzè, E.; Di Grazia, A.; Figliuzzi, M.M.; Caprioli, F.; Stolfi, C.; Monteleone, I.; et al. Neutrophil Extracellular Traps Sustain Inflammatory Signals in Ulcerative Colitis. J. Crohns Coliti 2019, 13, 772-784. [CrossRef] [PubMed] 
52. Gringhuis, S.I.; Wevers, B.A.; Kaptein, T.M.; Van Capel, T.M.M.; Theelen, B.; Boekhout, T.; De Jong, E.C.; Geijtenbeek, T.B.H. Selective C-Rel Activation via Malt1 Controls Anti-Fungal TH-17 Immunity by Dectin-1 and Dectin-2. PLoS Pathog. 2011, 7, e1001259. [CrossRef] [PubMed]

53. Bai, X.-D.; Liu, X.-H.; Tong, Q.-Y. Intestinal colonization withCandida albicansand mucosal immunity. World J. Gastroenterol. 2004, 10, 2124-2126. [CrossRef] [PubMed]

54. Cadwell, K.H.; Patel, K.K.; Maloney, N.S.; Liu, T.-C.; Ng, A.C.; Storer, C.; Head, R.D.; Xavier, R.; Stappenbeck, T.S.; Virgin, H.W. Virus-Plus-Susceptibility Gene Interaction Determines Crohn's Disease Gene Atg16L1 Phenotypes in Intestine. Cell 2010, 141, 1135-1145. [CrossRef]

55. Danese, S.; Fiorino, G.; Hindryckx, P.; Peyrin-Biroulet, L.; Danese, S. Novel therapeutic targets for inflammatory bowel disease. J. Autoimmun. 2017, 85, 103-116. [CrossRef]

56. Verstockt, B.; Ferrante, M.; Vermeire, S.; Van Assche, G. New treatment options for inflammatory bowel diseases. J. Gastroenterol. 2018, 53, 585-590. [CrossRef]

57. Kugathasan, S.; Denson, L.A.; Walters, T.D.; Kim, M.-O.; Marigorta, U.M.; Schirmer, M.; Mondal, K.; Liu, C.; Griffiths, A.; Noe, J.D.; et al. Prediction of complicated disease course for children newly diagnosed with Crohn's disease: A multicentre inception cohort study. Lancet 2017, 389, 1710-1718. [CrossRef]

58. Murthy, S.K.; Begum, J.; Benchimol, E.I.; Bernstein, C.N.; Kaplan, G.G.; McCurdy, J.D.; Singh, H.; Targownik, L.; Taljaard, M. Introduction of anti-TNF therapy has not yielded expected declines in hospitalisation and intestinal resection rates in inflammatory bowel diseases: A population-based interrupted time series study. Gut 2019, 69, 274-282. [CrossRef]

59. Coletta, M.; Paroni, M.; Alvisi, M.F.; De Luca, M.; Rulli, E.; Mazza, S.; Facciotti, F.; Lattanzi, G.; Strati, F.; Abrignani, S.; et al. Immunological Variables Associated With Clinical and Endoscopic Response to Vedolizumab in Patients With Inflammatory Bowel Diseases. J. Crohns Colitis 2020, 1-36. [CrossRef]

60. Bertani, L.; Baglietto, L.; Antonioli, L.; Fornai, M.; Tapete, G.; Albano, E.; Ceccarelli, L.; Mumolo, M.G.; Pellegrini, C.; Lucenteforte, E.; et al. Assessment of serum cytokines predicts clinical and endoscopic outcomes to vedolizumab in ulcerative colitis patients. Br. J. Clin. Pharmacol. 2020. [CrossRef]

61. Caviglia, G.P.; Rosso, C.; Stalla, F.; Rizzo, M.; Massano, A.; Abate, M.L.; Olivero, A.; Armandi, A.; Vanni, E.; Younes, R.; et al. On-Treatment Decrease of Serum Interleukin-6 as a Predictor of Clinical Response to Biologic Therapy in Patients with Inflammatory Bowel Diseases. J. Clin. Med. 2020, 9, 800. [CrossRef] [PubMed]

62. Ribaldone, D.G.; Caviglia, G.P.; Abdulle, A.; Pellicano, R.; Ditto, M.C.; Morino, M.; Fusaro, E.; Saracco, G.M.; Bugianesi, E.; Astegiano, M. Adalimumab Therapy Improves Intestinal Dysbiosis in Crohn's Disease. J. Clin. Med. 2019, 8, 1646. [CrossRef] [PubMed]

63. Digby-Bell, J.L.; Atreya, R.; Monteleone, G.; Powell, N. Interrogating host immunity to predict treatment response in inflammatory bowel disease. Nat. Rev. Gastroenterol. Hepatol. 2019, 17, 9-20. [CrossRef] [PubMed]

64. Scaldaferri, F.; Gerardi, V.; Lopetuso, L.R.; Del Zompo, F.; Mangiola, F.; Boškoski, I.; Bruno, G.; Petito, V.; Laterza, L.; Cammarota, G.; et al. Gut Microbial Flora, Prebiotics, and Probiotics in IBD: Their Current Usage and Utility. BioMed Res. Int. 2013, 2013, 1-9. [CrossRef]

65. Swidsinski, A.; Weber, J.; Loening-Baucke, V.; Hale, L.P.; Lochs, H. Spatial Organization and Composition of the Mucosal Flora in Patients with Inflammatory Bowel Disease. J. Clin. Microbiol. 2005, 43, 3380-3389. [CrossRef]

66. Mesa, N.G.; Camuesco, D.; Arribas, B.; Comalada, M.; Bailón, E.; Cueto-Sola, M.; Utrilla, P.; Nieto, A.; Zarzuelo, A.; Rodríguez-Cabezas, M.E.; et al. The intestinal anti-inflammatory effect of minocycline in experimental colitis involves both its immunomodulatory and antimicrobial properties. Pharmacol. Res. 2011, 63, 308-319. [CrossRef]

67. Kotze, P.G.; Shen, B.; Lightner, A.; Yamamoto, T.; Spinelli, A.; Ghosh, S.; Panaccione, R. Modern management of perianal fistulas in Crohn's disease: Future directions. Gut 2018, 67, 1181-1194. [CrossRef]

68. Nitzan, O.; Elias, M.; Peretz, A.; Saliba, W. Role of antibiotics for treatment of inflammatory bowel disease. World J. Gastroenterol. 2016, 22, 1078-1087. [CrossRef]

69. Lahat, G.; Halperin, D.; Barazovsky, E.; Shalit, I.; Rabau, M.; Klausner, J.; Fabian, I. Immunomodulatory effects of ciprofloxacin in TNBS-induced colitis in mice. Inflamm. Bowel Dis. 2007, 13, 557-565. [CrossRef]

70. Becker, E.; Bengs, S.; Aluri, S.; Opitz, L.; Atrott, K.; Stanzel, C.; Ruiz-Castro, P.A.; Rogler, G.; Frey-Wagner, I. Doxycycline, metronidazole and isotretinoin: Do they modify microRNA/mRNA expression profiles and function in murine T-cells? Sci. Rep. 2016, 6, 37082. [CrossRef] 
71. Fiorucci, S.; Distrutti, E.; Mencarelli, A.; Barbanti, M.; Palazzini, E.; Morelli, A. Inhibition of intestinal bacterial translocation with rifaximin modulates lamina propria monocytic cells reactivity and protects against inflammation in a rodent model of colitis. Digestion 2002, 66, 246-256. [CrossRef] [PubMed]

72. Sartor, R.B. Review article: The potential mechanisms of action of rifaximin in the management of inflammatory bowel diseases. Aliment. Pharmacol. Ther. 2015, 43, 27-36. [CrossRef] [PubMed]

73. Bermudez-Brito, M.; Borghuis, T.; Daniel, C.; Pot, B.; De Haan, B.J.; Faas, M.M.; De Vos, P. L. plantarum WCFS1 enhances Treg frequencies by activating DCs even in absence of sampling of bacteria in the Peyer Patches. Sci. Rep. 2018, 8, 1785. [CrossRef] [PubMed]

74. Lim, S.-M.; Jang, H.; Jang, S.-E.; Han, M.; Kim, D.-H. Lactobacillus fermentum IM12 attenuates inflammation in mice by inhibiting NF-кB-STAT3 signalling pathway. Benef. Microbes 2017, 8, 407-419. [CrossRef]

75. Zhai, Q.; Shen, X.; Cen, S.; Zhang, C.; Tian, F.; Zhao, J.; Zhang, H.; Xue, Y.; Chen, W. Screening of Lactobacillus salivarius strains from the feces of Chinese populations and the evaluation of their effects against intestinal inflammation in mice. Food Funct. 2020, 11, 221-235. [CrossRef]

76. Jang, S.-E.; Jeong, J.-J.; Kim, J.-K.; Han, M.J.; Kim, D.-H. Simultaneous Amelioratation of Colitis and Liver Injury in Mice by Bifidobacterium longum LC67 and Lactobacillus plantarum LC27. Sci. Rep. 2018, 8, 7500. [CrossRef]

77. Zhou, L.; Liu, D.; Xie, Y.; Yao, X.; Li, Y. Bifidobacterium infantis Induces Protective Colonic PD-L1 and Foxp3 Regulatory T Cells in an Acute Murine Experimental Model of Inflammatory Bowel Disease. Gut Liver 2019, 13, 430-439. [CrossRef]

78. Steimle, A.; Menz, S.; Bender, A.; Ball, B.; Weber, A.N.; Hagemann, T.; Lange, A.; Maerz, J.K.; Parusel, R.; Michaelis, L.; et al. Flagellin hypervariable region determines symbiotic properties of commensal Escherichia coli strains. PLoS Boil. 2019, 17, e3000334. [CrossRef]

79. Rodriguez-Nogales, A.; Algieri, F.; Mesa, J.G.; Vezza, T.; Utrilla, M.P.; Chueca, N.; Fernández-Caballero, J.A.; García, F.; Rodriguez-Cabezas, M.E.; Galvez, J. The Administration of Escherichia coli Nissle 1917 Ameliorates Development of DSS-Induced Colitis in Mice. Front. Pharmacol. 2018, 9, 468. [CrossRef]

80. Mariman, R.; Tielen, F.; Koning, F.; Nagelkerken, L. The Probiotic Mixture VSL\#3 Has Differential Effects on Intestinal Immune Parameters in Healthy Female BALB/c and C57BL/6 Mice. J. Nutr. 2015, 145, 1354-1361. [CrossRef]

81. Mimura, T.; Rizzello, F.; Helwig, U.; Poggioli, G.; Schreiber, S.; Talbot, I.C.; Nicholls, R.J.; Gionchetti, P.; Campieri, M.; Kamm, M.A. Once daily high dose probiotic therapy (VSL\#3) for maintaining remission in recurrent or refractory pouchitis. Gut 2004, 53, 108-114. [CrossRef] [PubMed]

82. Zhou, H.; Zhang, H.; Guan, L.; Zhang, Y.; Li, Y.; Sun, M. Mechanism and therapeutic effects of Saccharomyces boulardii on experimental colitis in mice. Mol. Med. Rep. 2018, 18, 5652-5662. [CrossRef] [PubMed]

83. Ishisono, K.; Mano, T.; Yabe, T.; Kitaguchi, K. Dietary Fiber Pectin Ameliorates Experimental Colitis in a Neutral Sugar Side Chain-Dependent Manner. Front. Immunol. 2019, 10, 2979. [CrossRef] [PubMed]

84. Grabinger, T.; Garzon, J.F.G.; Hausmann, M.; Geirnaert, A.; Lacroix, C.; Hennet, T. Alleviation of Intestinal Inflammation by Oral Supplementation With 2-Fucosyllactose in Mice. Front. Microbiol. 2019, 10, 1385. [CrossRef]

85. Kanwal, S.; Joseph, T.P.; Owusu, L.; Xiaomeng, R.; Meiqi, L.; Yi, X. A Polysaccharide Isolated from Dictyophora indusiata Promotes Recovery from Antibiotic-Driven Intestinal Dysbiosis and Improves Gut Epithelial Barrier Function in a Mouse Model. Nutrients 2018, 10, 1003. [CrossRef]

86. Kanwal, S.; Joseph, T.P.; Aliya, S.; Song, S.; Saleem, M.Z.; Nisar, M.A.; Wang, Y.; Meyiah, A.; Ma, Y.; Xin, Y. Attenuation of DSS induced colitis by Dictyophora indusiata polysaccharide (DIP) via modulation of gut microbiota and inflammatory related signaling pathways. J. Funct. Foods 2020, 64, 103641. [CrossRef]

87. Diling, C.; Xin, Y.; Chaoqun, Z.; Jian, Y.; Xiaocui, T.; Jun, C.; Ou, S.; Xie, Y. Extracts from Hericium erinaceus relieve inflammatory bowel disease by regulating immunity and gut microbiota. Oncotarget 2017, 8, 85838-85857. [CrossRef]

88. Ren, Y.; Geng, Y.; Du, Y.; Li, W.; Lu, Z.-M.; Xu, H.-Y.; Xu, G.-H.; Shi, J.-S.; Xu, Z.-H. Polysaccharide of Hericium erinaceus attenuates colitis in $\mathrm{C} 57 \mathrm{BL} / 6$ mice via regulation of oxidative stress, inflammation-related signaling pathways and modulating the composition of the gut microbiota. J. Nutr. Biochem. 2018, 57, 67-76. [CrossRef]

89. Li, R.; Kim, M.-H.; Sandhu, A.K.; Gao, C.; Gu, L. Muscadine Grape (Vitis rotundifolia) or Wine Phytochemicals Reduce Intestinal Inflammation in Mice with Dextran Sulfate Sodium-Induced Colitis. J. Agric. Food Chem. 2017, 65, 769-776. [CrossRef] 
90. Li, R.; Wang, G.P.; Whitlock, J.A.; Zhao, S.; Yagiz, Y.; Gu, L. Muscadine grapes (Vitis rotundifolia) and dealcoholized muscadine wine alleviated symptoms of colitis and protected against dysbiosis in mice exposed to dextran sulfate sodium. J. Funct. Foods 2020, 65, 103746. [CrossRef]

91. Shinde, T.; Perera, A.P.; Vemuri, R.; Gondalia, S.V.; Karpe, A.; Beale, D.J.; Shastri, S.; Southam, B.; Eri, R.; Stanley, R. Synbiotic Supplementation Containing Whole Plant Sugar Cane Fibre and Probiotic Spores Potentiates Protective Synergistic Effects in Mouse Model of IBD. Nutrients 2019, 11, 818. [CrossRef] [PubMed]

92. Shinde, T.; Perera, A.P.; Vemuri, R.; Gondalia, S.V.; Beale, D.J.; Karpe, A.V.; Shastri, S.; Basheer, W.; Southam, B.; Eri, R.; et al. Synbiotic supplementation with prebiotic green banana resistant starch and probiotic Bacillus coagulans spores ameliorates gut inflammation in mouse model of inflammatory bowel diseases. Eur. J. Nutr. 2020, 1-21. [CrossRef]

93. Altun, H.K.; Yildiz, E.A.; Akin, M. Effects of synbiotic therapy in mild-to-moderately active ulcerative colitis: A randomized placebo-controlled study. Turk. J. Gastroenterol. 2019, 30, 313-320. [CrossRef] [PubMed]

94. Tsilingiri, K.; Rescigno, M. Postbiotics: What else? Benef. Microbes 2013, 4, 101-107. [CrossRef]

95. Yan, F.; Liu, L.; Cao, H.; Moore, D.J.; Washington, M.K.; Wang, B.; Peek, R.M.; Acra, S.A.; Polk, D.B. Neonatal colonization of mice with LGG promotes intestinal development and decreases susceptibility to colitis in adulthood. Mucosal Immunol. 2016, 10, 117-127. [CrossRef] [PubMed]

96. Yan, F.; Cao, H.; Cover, T.L.; Whitehead, R.; Washington, M.K.; Polk, D.B. Soluble Proteins Produced by Probiotic Bacteria Regulate Intestinal Epithelial Cell Survival and Growth. Gastroenterology 2007, 132, 562-575. [CrossRef]

97. Yan, F.; Cao, H.; Cover, T.L.; Washington, M.K.; Shi, Y.; Liu, L.; Chaturvedi, R.; Peek, R.M.; Wilson, K.T.; Polk, D.B. Colon-specific delivery of a probiotic-derived soluble protein ameliorates intestinal inflammation in mice through an EGFR-dependent mechanism. J. Clin. Investig. 2011, 121, 2242-2253. [CrossRef]

98. Shen, X.; Liu, L.; Peek, R.M.; Acra, S.A.; Moore, D.J.; Wilson, K.T.; He, F.; Polk, D.B.; Yan, F. Supplementation of p40, a Lactobacillus rhamnosus GG-derived protein, in early life promotes epidermal growth factor receptor-dependent intestinal development and long-term health outcomes. Mucosal Immunol. 2018, 11, 1316-1328. [CrossRef]

99. Izuddin, W.I.; Loh, T.C.; Foo, H.L.; Samsudin, A.A.; Humam, A.M. Postbiotic L. plantarum RG14 improves ruminal epithelium growth, immune status and upregulates the intestinal barrier function in post-weaning lambs. Sci. Rep. 2019, 9, 9938. [CrossRef]

100. Ren, Q.; Yang, B.; Zhang, H.; Ross, R.P.; Stanton, C.; Chen, H.; Chen, W. c9, t11, c15-CLNA and t9, t11, c15-CLNA from Lactobacillus plantarum ZS2058 Ameliorate Dextran Sodium Sulfate-Induced Colitis in Mice. J. Agric. Food Chem. 2020, 68, 3758-3769. [CrossRef]

101. Bossche, L.V.D.; Hindryckx, P.; Devisscher, L.; Devriese, S.; Van Welden, S.; Holvoet, T.; Vilchez-Vargas, R.; Vital, M.; Pieper, D.H.; Bussche, J.V.; et al. Ursodeoxycholic Acid and Its Taurine- or Glycine-Conjugated Species Reduce Colitogenic Dysbiosis and Equally Suppress Experimental Colitis in Mice. Appl. Environ. Microbiol. 2017, 83, e02766-16. [CrossRef]

102. Zhou, L.; Zhang, M.; Wang, Y.; Dorfman, R.G.; Liu, H.; Yu, T.; Chen, X.; Tang, D.; Xu, L.; Yin, Y.; et al. Faecalibacterium prausnitzii Produces Butyrate to Maintain Th17/Treg Balance and to Ameliorate Colorectal Colitis by Inhibiting Histone Deacetylase 1. Inflamm. Bowel Dis. 2018, 24, 1926-1940. [CrossRef] [PubMed]

103. Simeoli, R.; Raso, G.M.; Pirozzi, C.; Lama, A.; Santoro, A.; Russo, R.; Montero-Melendez, T.; Canani, R.B.; Calignano, A.; Perretti, M.; et al. An orally administered butyrate-releasing derivative reduces neutrophil recruitment and inflammation in dextran sulphate sodium-induced murine colitis. Br. J. Pharmacol. 2016, 174, 1484-1496. [CrossRef] [PubMed]

104. Zha, Z.; Lv, Y.; Tang, H.; Li, T.; Miao, Y.; Cheng, J.; Wang, G.; Tan, Y.; Zhu, Y.; Xing, X.; et al. An orally administered butyrate-releasing xylan derivative reduces inflammation in dextran sulphate sodium-induced murine colitis. Int. J. Boil. Macromol. 2019. [CrossRef]

105. Facchin, S.; Vitulo, N.; Perini, B.; Buda, A.; Zingone, F.; Romualdi, C.; D’Incà, R.; Savarino, E. P655 Microencapsulated Sodium Butyrate significantly modifies the microbiota in patients with inflammatory bowel disease mimicking prebiotic activity and proving effects on the treatment of the disease. J. Crohns Colitis 2019, 13, S446-S447. [CrossRef]

106. Burrello, C.; Garavaglia, F.; Cribiù, F.M.; Ercoli, G.; Lopez, G.; Troisi, J.; Colucci, A.; Guglietta, S.; Carloni, S.; Guglielmetti, S.; et al. Therapeutic faecal microbiota transplantation controls intestinal inflammation through IL10 secretion by immune cells. Nat. Commun. 2018, 9, 5184. [CrossRef] 
107. Burrello, C.; Giuffrè, M.R.; Macandog, A.D.; Diaz-Basabe, A.; Cribiù, F.M.; Lopez, G.; Borgo, F.C.; Nezi, L.; Caprioli, F.; Vecchi, M.; et al. Fecal Microbiota Transplantation Controls Murine Chronic Intestinal Inflammation by Modulating Immune Cell Functions and Gut Microbiota Composition. Cells 2019, 8, 517. [CrossRef]

108. Jacob, V.; Crawford, C.; Cohen-Mekelburg, S.; Viladomiu, M.; Putzel, G.G.; Schneider, Y.; Chabouni, F.; O’Neil, S.; Bosworth, B.; Woo, V.; et al. Single Delivery of High-Diversity Fecal Microbiota Preparation by Colonoscopy Is Safe and Effective in Increasing Microbial Diversity in Active Ulcerative Colitis. Inflamm. Bowel Dis. 2017, 23, 903-911. [CrossRef]

109. Quraishi, M.N.; Oo, Y.H.; Beggs, A.; Withers, D.; Acharjee, A.; Sharma, N.; Manzoor, S.; Hart, A.L.; Gaya, D.R.; Loman, N.J.; et al. OP09 Immunomodulatory mechanisms of faecal microbiota transplantation are associated with clinical response in ulcerative colitis: Early results from STOP-Colitis. J. Crohns Colitis 2020, 14, S010. [CrossRef]

110. Tian, Y.; Zhou, Y.; Huang, S.; Li, J.; Zhao, K.; Li, X.; Wen, X.; Li, X.-A. Fecal microbiota transplantation for ulcerative colitis: A prospective clinical study. BMC Gastroenterol. 2019, 19, 116. [CrossRef]

111. Sokol, H.; Network, S.-A.I.; Landman, C.; Seksik, P.; Berard, L.; Montil, M.; Nion-Larmurier, I.; Bourrier, A.; Le Gall, G.; Lalande, V.; et al. Fecal microbiota transplantation to maintain remission in Crohn's disease: A pilot randomized controlled study. Microbiome 2020, 8, 1-14. [CrossRef] [PubMed]

112. Wieërs, G.; Belkhir, L.; Enaud, R.; Leclercq, S.; De Foy, J.-M.P.; Dequenne, I.; De Timary, P.; Cani, P.D. How Probiotics Affect the Microbiota. Front. Microbiol. 2020, 9, 454. [CrossRef] [PubMed]

113. Markowiak, P.; Śliżewska, K. Effects of Probiotics, Prebiotics, and Synbiotics on Human Health. Nutrients 2017, 9, 1021. [CrossRef] [PubMed]

114. Plant, L.; Conway, P. Association of Lactobacillus spp. with Peyer's Patches in Mice. Clin. Diagn. Lab. Immunol. 2001, 8, 320-324. [CrossRef] [PubMed]

115. Chieppa, M.; Rescigno, M.; Huang, A.Y.C.; Germain, R.N. Dynamic imaging of dendritic cell extension into the small bowel lumen in response to epithelial cell TLR engagement. J. Exp. Med. 2006, 203, 2841-2852. [CrossRef]

116. Scaldaferri, F.; Gerardi, V.; Mangiola, F.; Lopetuso, L.R.; Marco, P.; Petito, V.; Papa, A.; Stojanovic, J.; Poscia, A.; Cammarota, G.; et al. Role and mechanisms of action ofEscherichia coliNissle 1917 in the maintenance of remission in ulcerative colitis patients: An update. World J. Gastroenterol. 2016, 22, 5505-5511. [CrossRef] [PubMed]

117. Byndloss, M.X.; Olsan, E.E.; Rivera-Chávez, F.; Tiffany, C.R.; Cevallos, S.A.; Lokken, K.L.; Torres, T.P.; Byndloss, A.J.; Faber, F.; Gao, Y.; et al. Microbiota-activated PPAR- $\gamma$ signaling inhibits dysbiotic Enterobacteriaceae expansion. Science 2017, 357, 570-575. [CrossRef]

118. Chapman, T.M.; Plosker, G.L.; Figgitt, D.P. VSL\#3 probiotic mixture: A review of its use in chronic inflammatory bowel diseases. Drugs 2006, 66, 1371-1387.

119. Mar, J.S.; Nagalingam, N.A.; Song, Y.; Onizawa, M.; Lee, J.W.; Lynch, S.V. Amelioration of DSS-induced murine colitis by VSL\#3 supplementation is primarily associated with changes in ileal microbiota composition. Gut Microbes 2014, 5, 494-503. [CrossRef]

120. De Nitto, D.; Sarra, M.; Pallone, F.; Monteleone, G. Interleukin-21 triggers effector cell responses in the gut. World J. Gastroenterol. 2010, 16, 3638-3641. [CrossRef]

121. Dang, X.; Xu, M.; Liu, D.; Zhou, D.; Yang, W. Assessing the efficacy and safety of fecal microbiota transplantation and probiotic VSL\#3 for active ulcerative colitis: A systematic review and meta-analysis. PLoS ONE 2020, 15, e0228846. [CrossRef]

122. Derwa, Y.; Gracie, D.J.; Hamlin, P.J.; Ford, A.C. Systematic review with meta-analysis: The efficacy of probiotics in inflammatory bowel disease. Aliment. Pharmacol. Ther. 2017, 46, 389-400. [CrossRef] [PubMed]

123. Jia, K.; Tong, X.; Wang, R.; Song, X. The clinical effects of probiotics for inflammatory bowel disease. Medicine 2018, 97, e13792. [CrossRef] [PubMed]

124. The Integrative HMP (iHMP) Research Network Consortium; Integrative HMP (iHMP) Research Network Consortium; Buck, G.A. The Integrative Human Microbiome Project. Nature 2019, 569, 641-648. [CrossRef]

125. Zmora, N.; Zilberman-Schapira, G.; Suez, J.; Mor, U.; Dori-Bachash, M.; Bashiardes, S.; Kotler, E.; Zur, M.; Regev-Lehavi, D.; Brik, R.B.-Z.; et al. Personalized Gut Mucosal Colonization Resistance to Empiric Probiotics Is Associated with Unique Host and Microbiome Features. Cell 2018, 174, 1388-1405.e21. [CrossRef] 
126. O'Toole, P.W.; Marchesi, J.R.; Hill, C. Next-generation probiotics: The spectrum from probiotics to live biotherapeutics. Nat. Microbiol. 2017, 2, 17057. [CrossRef]

127. Vandenbroucke, K.; De Haard, H.; Beirnaert, E.; Dreier, T.; Lauwereys, M.; Huyck, L.; Van Huysse, J.; Demetter, P.; Steidler, L.; Remaut, E.; et al. Orally administered L. lactis secreting an anti-TNF Nanobody demonstrate efficacy in chronic colitis. Mucosal Immunol. 2009, 3, 49-56. [CrossRef]

128. Takahashi, K.; Nishida, A.; Fujimoto, T.; Fujii, M.; Shioya, M.; Imaeda, H.; Inatomi, O.; Bamba, S.; Andoh, A.; Sugimoto, M. Reduced Abundance of Butyrate-Producing Bacteria Species in the Fecal Microbial Community in Crohn's Disease. Digestion 2016, 93, 59-65. [CrossRef]

129. Kumari, R.; Ahuja, V.; Paul, J. Fluctuations in butyrate-producing bacteria in ulcerative colitis patients of North India. World J. Gastroenterol. 2013, 19, 3404-3414. [CrossRef]

130. Silveira, A.L.M.; Ferreira, A.V.M.; Oliveira, M.C.; Rachid, M.A.; Sousa, L.F.D.C.; Martins, F.D.S.; Gomes-Santos, A.C.; Vieira, A.; Teixeira, M.M. Preventive rather than therapeutic treatment with high fiber diet attenuates clinical and inflammatory markers of acute and chronic DSS-induced colitis in mice. Eur. J. Nutr. 2015, 56, 179-191. [CrossRef]

131. Llewellyn, S.R.; Britton, G.; Contijoch, E.; Vennaro, O.H.; Mortha, A.; Colombel, J.-F.; Grinspan, A.; Clemente, J.C.; Merad, M.; Faith, J.J. Interactions Between Diet and the Intestinal Microbiota Alter Intestinal Permeability and Colitis Severity in Mice. Gastroenterology 2017, 154, 1037-1046.e2. [CrossRef] [PubMed]

132. Cueva, C.; Sánchez-Patán, F.; Monagas, M.; Walton, G.E.; Gibson, G.R.; Martín-Álvarez, P.J.; Bartolomé, B.; Moreno-Arribas, M.V. In vitrofermentation of grape seed flavan-3-ol fractions by human faecal microbiota: Changes in microbial groups and phenolic metabolites. FEMS Microbiol. Ecol. 2012, 83, 792-805. [CrossRef] [PubMed]

133. Pandey, K.R.; Naik, S.R.; Vakil, B.V. Probiotics, prebiotics and synbiotics-A review. J. Food Sci. Technol. 2015, 52, 7577-7587. [CrossRef] [PubMed]

134. Swennen, K.; Courtin, C.M.; Delcour, J.A. Non-digestible Oligosaccharides with Prebiotic Properties. Crit. Rev. Food Sci. Nutr. 2006, 46, 459-471. [CrossRef]

135. Lucendo, A.J.; De Rezende, L.C. Importance of nutrition in inflammatory bowel disease. World J. Gastroenterol. 2009, 15, 2081-2088. [CrossRef]

136. Collado, M.; Vinderola, G.; Salminen, S. Postbiotics: Facts and open questions. A position paper on the need for a consensus definition. Benef. Microbes 2019, 10, 711-719. [CrossRef]

137. Mosca, F.; Giannì, M.L.; Rescigno, M. Can Postbiotics Represent a New Strategy for NEC? In Advances in Experimental Medicine and Biology; Springer Science and Business Media LLC.: Berlin/Heidelberg, Germany, 2019; pp. 37-45.

138. Russo, E.; Giudici, F.; Fiorindi, C.; Ficari, F.; Scaringi, S.; Amedei, A. Immunomodulating Activity and Therapeutic Effects of Short Chain Fatty Acids and Tryptophan Post-biotics in Inflammatory Bowel Disease. Front. Immunol. 2019, 10, 2754. [CrossRef]

139. Mileti, E.; Matteoli, G.; Iliev, I.D.; Rescigno, M. Comparison of the Immunomodulatory Properties of Three Probiotic Strains of Lactobacilli Using Complex Culture Systems: Prediction for In Vivo Efficacy. PLoS ONE 2009, 4, e7056. [CrossRef]

140. Katerina Tsilingiri, T.; Barbosa, T.; Penna, G.; Caprioli, F.; Sonzogni, A.; Viale, G.; Rescigno, M. Probiotic and postbiotic activity in health and disease: Comparison on a novel polarised ex-vivo organ culture model. Gut 2001, 61, 1007-1015. [CrossRef]

141. Hidalgo-Cantabrana, C.; Moro-García, M.A.; Blanco-Miguez, A.; Fdez-Riverola, F.; Lourenço, A.; Alonso-Arias, R.; Sánchez, B. In Silico Screening of the Human Gut Metaproteome Identifies Th17-Promoting Peptides Encrypted in Proteins of Commensal Bacteria. Front. Microbiol. 2017, 8, 1726. [CrossRef]

142. Fernández-Tomé, S.; Montalban-Arques, A.; Díaz-Guerra, A.; Galvan-Roman, J.M.; Marin, A.C.; Mora-Gutiérrez, I.; Moreno, L.O.; Santander, C.; Sánchez, B.; Chaparro, M.; et al. Peptides encrypted in the human intestinal microbial-exoproteome as novel biomarkers and immunomodulatory compounds in the gastrointestinal tract. J. Funct. Foods 2019, 52, 459-468. [CrossRef]

143. Takeda, Y.; Nakase, H.; Namba, K.; Inoue, S.; Ueno, S.; Uza, N.; Chiba, T. Upregulation of T-bet and tight junction molecules by Bifidobactrium longum improves colonic inflammation of ulcerative colitis. Inflamm. Bowel Dis. 2009, 15, 1617-1618. [CrossRef] [PubMed] 
144. Tamaki, H.; Nakase, H.; Inoue, S.; Kawanami, C.; Itani, T.; Ohana, M.; Kusaka, T.; Uose, S.; Hisatsune, H.; Tojo, M.; et al. Efficacy of probiotic treatment with Bifidobacterium longum 536 for induction of remission in active ulcerative colitis: A randomized, double-blinded, placebo-controlled multicenter trial. Dig. Endosc. 2015, 28, 67-74. [CrossRef] [PubMed]

145. Fernández-Tomé, S.; Marin, A.C.; Moreno, L.O.; Baldan-Martin, M.; Mora-Gutiérrez, I.; Lanas-Gimeno, A.; Moreno-Monteagudo, J.A.; Santander, C.; Sánchez, B.; Chaparro, M.; et al. Immunomodulatory Effect of Gut Microbiota-Derived Bioactive Peptides on Human Immune System from Healthy Controls and Patients with Inflammatory Bowel Disease. Nutrients 2019, 11, 2605. [CrossRef] [PubMed]

146. Quraishi, M.N.; Shaheen, W.; Oo, Y.H.; Iqbal, T.H. Immunological mechanisms underpinning faecal microbiota transplantation for the treatment of inflammatory bowel disease. Clin. Exp. Immunol. 2019, 199, 24-38. [CrossRef] [PubMed]

147. Quraishi, M.N.; Widlak, M.; Bhala, N.; Moore, D.; Price, M.; Sharma, N.; Iqbal, T.H. Systematic review with meta-analysis: The efficacy of faecal microbiota transplantation for the treatment of recurrent and refractory Clostridium difficile infection. Aliment. Pharmacol. Ther. 2017, 46, 479-493. [CrossRef]

148. Baktash, A.; Terveer, E.M.; Zwittink, R.D.; Hornung, B.V.H.; Corver, J.; Kuijper, E.J.; Smits, W.K. Mechanistic Insights in the Success of Fecal Microbiota Transplants for the Treatment of Clostridium difficile Infections. Front. Microbiol. 2018, 9, 1242. [CrossRef]

149. Britton, G.; Contijoch, E.; Mogno, I.; Vennaro, O.H.; Llewellyn, S.R.; Ng, R.; Li, Z.; Mortha, A.; Merad, M.; Das, A.; et al. Microbiotas from Humans with Inflammatory Bowel Disease Alter the Balance of Gut Th17 and ROR $\gamma t+$ Regulatory T Cells and Exacerbate Colitis in Mice. Immunology 2019, 50, 212-224.e4. [CrossRef]

150. Paramsothy, S.; Paramsothy, R.; Rubin, D.T.; Kamm, M.A.; Kaakoush, N.O.; Mitchell, H.M.; Castaño-Rodríguez, N. Faecal Microbiota Transplantation for Inflammatory Bowel Disease: A Systematic Review and Meta-analysis. J. Crohns Colitis 2017, 11, 1180-1199. [CrossRef]

151. Li, X.; Leonardi, I.; Semon, A.; Doron, I.; Gao, I.H.; Putzel, G.G.; Kim, Y.; Kabata, H.; Artis, D.; Fiers, W.D.; et al. Response to Fungal Dysbiosis by Gut-Resident CX3CR1+ Mononuclear Phagocytes Aggravates Allergic Airway Disease. Cell Host Microbe 2018, 24, 847-856.e4. [CrossRef]

152. Leonardi, I.; Paramsothy, S.; Doron, I.; Semon, A.; Kaakoush, N.O.; Clemente, J.C.; Faith, J.J.; Borody, T.J.; Mitchell, H.M.; Colombel, J.-F.; et al. Fungal Trans-kingdom Dynamics Linked to Responsiveness to Fecal Microbiota Transplantation (FMT) Therapy in Ulcerative Colitis. Cell Host Microbe 2020, 27, 823-829.e3. [CrossRef] [PubMed]

153. Paramsothy, S.; Kamm, M.A.; Kaakoush, N.O.; Walsh, A.J.; Bogaerde, J.V.D.; Samuel, D.; Leong, R.W.; Connor, S.; Ng, W.; Paramsothy, R.; et al. Multidonor intensive faecal microbiota transplantation for active ulcerative colitis: A randomised placebo-controlled trial. Lancet 2017, 389, 1218-1228. [CrossRef]

154. Moayyedi, P.; Surette, M.; Kim, P.T.; Libertucci, J.; Wolfe, M.; Onischi, C.; Armstrong, D.; Marshall, J.K.; Kassam, Z.; Reinisch, W.; et al. Fecal Microbiota Transplantation Induces Remission in Patients With Active Ulcerative Colitis in a Randomized Controlled Trial. Gastroenterology 2015, 149, 102-109.e6. [CrossRef] [PubMed]

155. Costello, S.P.; Hughes, P.A.; Waters, O.; Bryant, R.V.; Vincent, A.D.; Blatchford, P.; Katsikeros, R.; Makanyanga, J.; Campaniello, M.A.; Mavrangelos, C.; et al. Effect of Fecal Microbiota Transplantation on 8-Week Remission in Patients With Ulcerative Colitis. JAMA 2019, 321, 156-164. [CrossRef]

156. Rossen, N.G.; Fuentes, S.; Van Der Spek, M.J.; Tijssen, J.G.; Hartman, J.H.; Duflou, A.; Löwenberg, M.; Brink, G.R.V.D.; Mathus-Vliegen, E.M.; De Vos, W.M.; et al. Findings From a Randomized Controlled Trial of Fecal Transplantation for Patients With Ulcerative Colitis. Gastroenterology 2015, 149, 110-118.e4. [CrossRef]

157. Fecal Microbiota Transplant in the Treatment of Ulcerative Colitis (FMTUC). Available online: https://clinicaltrials. gov/ct2/show/NCT02390726?term=NCT02390726\&draw=2\&rank=1. (accessed on 19 February 2015).

158. Baumgart, D.C.; Carding, S.R. Inflammatory bowel disease: Cause and immunobiology. Lancet 2007, 369, 1627-1640. [CrossRef]

(C) 2020 by the authors. Licensee MDPI, Basel, Switzerland. This article is an open access article distributed under the terms and conditions of the Creative Commons Attribution (CC BY) license (http://creativecommons.org/licenses/by/4.0/). 